\title{
Origin of groundwater salinity and hydrogeochemical processes in a confined coastal karst aquifer: A cause of the Mandalia Bay (southeastern Aegean Sea coasts)
}

\author{
İpek F. Barut ${ }^{1 *}$ \\ ${ }^{1}$ Istanbul University, Institute of Marine Sciences and Management, 34134 VEFA, FATIH, ISTANBUL-TR
}

Corresponding author. Tel: +902124400000

Received 19 July 2014

E-mail: barutif@istanbul.edu.tr

Accepted 30 Sept. 2014

\begin{abstract}
There are numerous springs and wells within the context of this research about the part of northern and northeastern in The Mandalia Bay which has an important role regarding tourism and agriculture in Turkey's Southeastern Aegean coasts. There are an important springs in this basin, as the high discharge with values Ekinambari springs for 5385 l/s, Savrankoy springs for 4215 1/s, Avsar springs for the 1000 1/s, Sucikti springs (Karacahisar) to $400 \mathrm{l} / \mathrm{s}$. The change of the total annual flow observations compatible with each other, an increase was observed in springs of Ekinambari, Savrankoy and Sucikti. The springs group of Ekinambari, is located from the sea about $10 \mathrm{~km}$ away in the alluvium. These springs were at the foot of the hill at various points at $46 \mathrm{~m}$ altitude, different flow rates and temperatures, allochthonous limestone flows from the broken system. The springs in the investigation area, which was measured in the high current values, of Savrankoy and Ekinambari springs monthly average current value of resources are examined, the difference between the current value is less than by months. In this spring waters of high salinity values $(0,5$ to $36,2 \%)$ was determined.

In this study were questioned as origin of ground water salinity from deep aquifer formations or from current sea water? In the case of salinity, in spring waters have occurred on deep towards the karstic levels of limestones from sea water is saturation. Examined the water was fed by a high level, the transition period is short and in aquifer in contact with shallow circulating water for a short time is. They could say that mixing different amounts of surface water were also. Given these results, the most important spring waters for the region (Savrankoy, Ekinambar1, etc.,) of ground water movement in karstic system pressure and decreasing/increasing rate of interventions performed in the presence of a seawater can be mentioned.
\end{abstract}

Keywords: hydrogeology, hydrogeochemistry, Mandalia Bay (SE Aegean Sea coasts), salty karstic springs, seawater mixing.

\section{Introduction}

A hydrochemical study of marine intrusion seems simple, given that in the majority of cases the seawater represents one extreme of the freshwater-saline water mixture. However, this mixing process is superimposed by other processes (Sanchez-Martos et al., 1999), which modify the characteristics of the mixing water, due to the initial lack of equilibrium between the aquifer matrix and the mixing water. The carbonate and clay minerals behave as geochemical buffers of salinization: they are liable to dissolution and precipitation, dolomitization-dedolomitization and cation exchange, all of which act in opposition to changes induced by seawater intrusion.

Along with $\mathrm{SO}_{4}$ reduction, these processes are the major modifying phenomena of the hydrochemistry of waters salinized by seawater intrusion (Gimenez, 1994; Jones et al., 1999). Representative hydrochemical facies in the aquifer show a marked difference between the headwaters, where the dominant type is $\mathrm{Ca}$ $\mathrm{HCO}_{3}$, and the coastal strip, where a $\mathrm{NaCl}$ facies dominates, and this progression clearly indicates freshwater and seawater mixing (Pulido-Leboeuf, 2002). 
The research zone includes the north and northeast - east most regions of the Mandalia Bay, which are located in the southeastern Aegean coasts of Turkey (Figure 1). The northern and eastern sides of Mugla-Milas Basin are surrounded by mountains, and the eastern side is surrounded by the sea. The Milas Ekinambari and Savrankoy Basin includes in the north at the part of northeastern Bafa Lake. It is located in the east - west and northwestern- southeastern directions, and between $27^{\circ} 30^{\prime}-28^{\circ} 06^{\prime}$ E longitudes and $37^{\circ} 04^{\prime}$ - $37^{\circ} 32^{\prime} \mathrm{N}$ latitudes. The basin covers an area of $1221 \mathrm{~km}^{2}$. The research area is based on the areas where the karstic lime stones are bordered by the impermeable stones. During this research, studies intended to investigate water quality and amount, and an explanation of the hydrogeological circulation model have been developed, based on carefully documented observations of certain characteristics significant to the brackish/saline karstic springs of the Milas Basin.

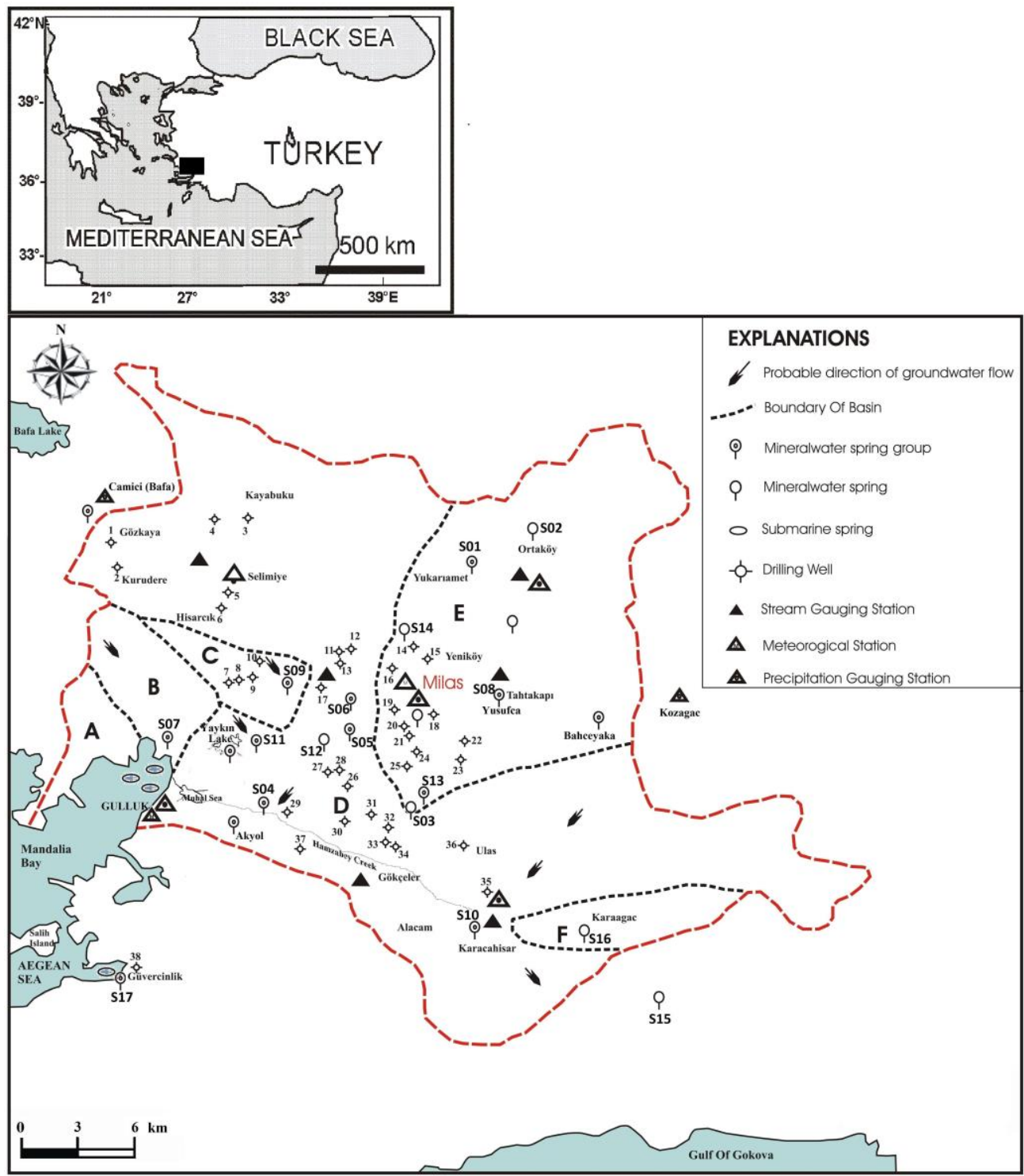

Fig. 1. Location map of Milas Basin's and samples of wells and mineral spring waters map of Milas Basin's. 
High salinity values (Salinity $\%=0.5-36.2$ ) have been measured in the waters which are discharged from the brackish/saline karstic springs of the Milas Basin (Barut, 2001; Barut and Gurpinar, 2005). For this reason, the hydrogeochemical characteristics of the springs and wells should be exposed by performing hydrogeologic observations in the feeding areas to determine the parameters which cause salinity. Creating a model which can explain the reasons for salinity is the purpose of this study. Within this scope, studies to determine the water quality and amount have been performed using meteorological and hydrogeological data; an approach to the hydrogeological circulation model has also been developed by taking into consideration the characteristics of the brackish/saline karstic springs of the Milas Basin. Milas Basin is the most important karst spring waters Ekinambar1Savranköy in high flow and high salinity characteristics. Therefore, these spring waters particularly in the area were taken into consideration in the basin water were investigated.

Stacking of otochone and allochotone stones, geologic and hydrogeologic evolution and impermeable borders are effective on the hydrogeology of the region to take a shape. In the areas where the carstic lime stones are scattered, surface rain areas and feeding of ground water show differences. As a result of mass seismic activity in the region, the movement of groundwater is controlled by tectonism. Hence units of allochtone stackings create a partition and as a result of occurring discontinuities because of tectonic activities, marine water entrances exist. The marine water which mixes with the groundwaters decrease the economical value of these waters as for irrigation and drinking usage.

The main objective of this study was to determine if the principal determinant of groundwater salinization in the part of the aquifer that lies closest to the coast is due solely to the mixing of freshwater and seawater or if there are other hydrochemical processes involved that modify the theoretical freshwater-seawater mixture. An understanding of the geochemical processes that occur along the fresh water-seawater contact is important because these affect the permeability of the rock, in carbonated aquifers, and therefore the extent of marine intrusion suffered by an aquifer. In semiarid areas, excessive water withdrawal for agricultural land where the summer water demand is supplied almost exclusively from groundwater resources, this behaviour assumes the utmost importance because of the economic ruin that would be the result of contamination of the aquifer by salinization.

\section{Geological and Hydrogeological Characteristics of The Investigation Area}

Quaternary formations at the region generally in the most recent geological period was created. The epirogenic movements have increased the erosion by means of streams and the alluvium areas of the Quaternary. In the region some parts of the fault block has been resulted in the erosion surfaces by means of increase. Limnogeotic sediment areas have occured in some parts of the fault block by means of collapse (Kayan and Klemas, 1978). Tectonic movements have caused depressions in various scales around the metamorphic belt controlled by the faults.

The many bays and gulfs have been occurred at the southwestern Anatolia coasts. The rift in east-west direction along the Gulf of Gokova, and the transgression in the Holocene covering of the flat areas has resulted in the movement of the sea towards the valleys in the northern parts, which has created the seawater intrusions. Of the geology of the Milas Basin being formed at the southern flank of the Menderes Massive could be distinguished as an important research area. There are sections of the authocthonous forming the base. The allochthonous units are dragging and resting on the base rocks, and new authocthonous and allocthonous units are been forming.

Seismic activity is very high in the district area and due to rapid orogenesis and intensive erosion the accumulation of cones has occurred along the fault lines, along with thick alluvium sedimentation in the grabens (Barut, 2001). As a result of mass seismic activity in the region, the movement of groundwater is controlled by tectonism. Because of the feeding on autochthon and allochthon units east of the 
basin, groundwaters move northwest, through highest discharge at the region.

Ekinambari and Savrankoy springs which the

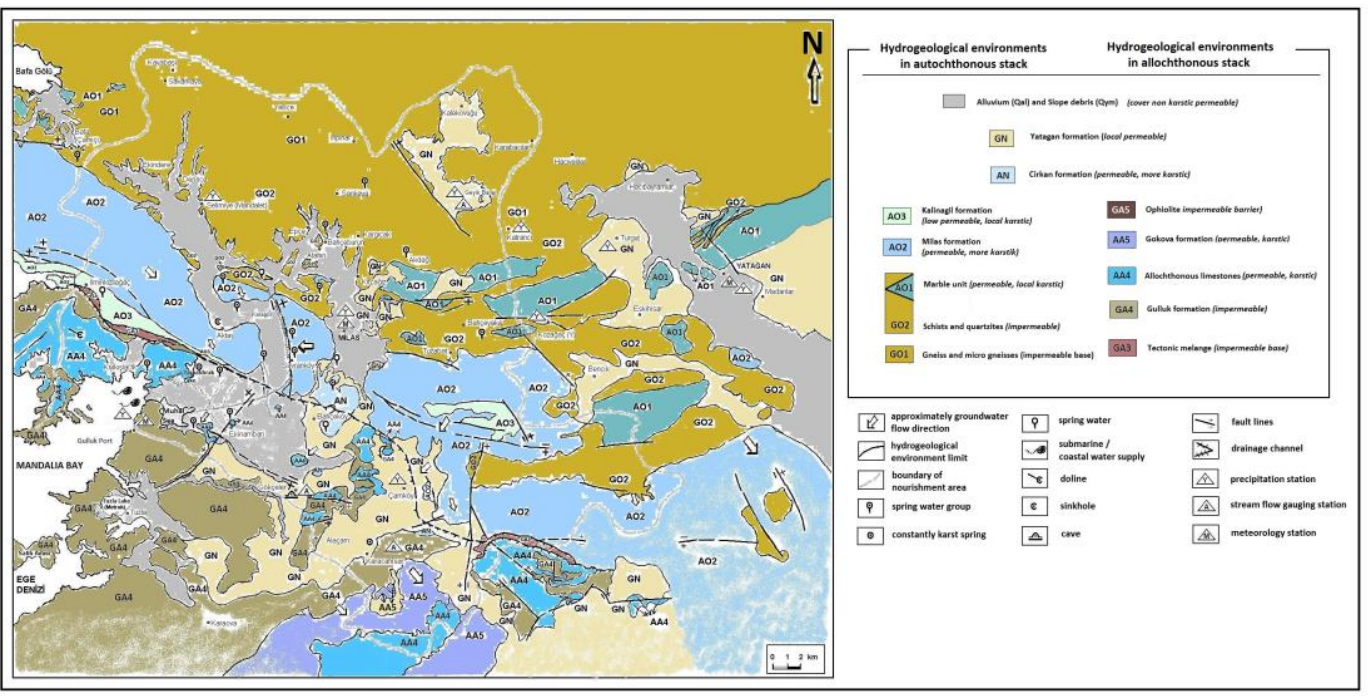

Fig.2. Hydrogeological map of Milas Basin's (Barut, 2001)

Hydrogeological systems in the region have been influenced by the distribution of autochthon and allochthon rocks, geological and hydrogeological evolution, and the occurance of differences in the impermeable limitations (evident in the formations). However, late Paleocene red limestones around the Milas-Mugla are proposed as the key bed for distinguishing autochthon and allochthon series (Eroskay et al., 1992; Onhon et al., 1998; Barut, 2001). Marble, calc-schist and quartzite zones within the metamorphites of Menderes Massive (marble, calc-schist, quartzite, various schist and gneiss) are permeable and form the most important mineral water aquifer. The distribution of karstic limestones have differences according to the boundaries of the surface precipitation areas and catchment ground water areas. In this respect, for determination of the catchment area, investigation of the rocks in autochthon and allochthon nappes has found them to be as follows: impermeable (barrier), permeable (aquifer) rocks, and neogene permeable overburden (Figure 2).

In the region, groundwaters run out from definite locations and mostly from the karstic spring waters that have high flow rate. While the groundwaters are fed by the rainwater filtered from the autochthon and allochthon stacking, the movement of the groundwaters is controlled by the autochthon and allochthon stacking that blocks porous carbonated rocks (and by tectonics). To the north of the catchment, the lens-like marbles existing in the schist are the feeding areas through which the rainwater creeps. A run-out has happened at some locations of the spring waters with low flow rate, schist and gneisses. There are hydrogeological properties of the formations as four units in the investigation area.

\section{Impermeable units}

The gneisses and micro gneisses of Menderes Massive, in general, are impermeable and are at the bottom. However, there have been locations where samples were obtained which were second permeable and exhibited porosity by the joint, by fracture, by foliasion, by schistosity, and by fault bases. Springs have been nourished, in connection by the fracture and crack zones and as near the surface, partially due to decomposition. During the study, an area has been observed by us at a zone near the surface, where decomposition is present involving a group of gneiss and schist coming out near the Labranda and Bahceburun springs around the northeastern part of Milas. In terms of groundwater recharge areas are generally gneissic rocks was adopted as impermeable (Barut, 2001). 
Schists and Quartzites; gneiss have been surrounded with the schists on south of the zone. This band has impermeable and clayey schist, mica schist, chlorite schist, fillat, quartzite, calc-schist, and with marble lenses are. According to regional hydrogeological observations, karstification has been observed in the Sodra and Mahuf Ridges in the northern part of Sodra Mountain. Marbles of transitive schists in large fields have been evaluated as karstic in origin and useful in the location of aquifers. However, schist and quartzites are mainly impermeable.

Techtonical Mélange sometimes form an impermeable boundary or relief and are disordered in the allochthon unit with ophiolite (Barut, 2001). Gulluk Formation is at the bottom of the allochthon sequence, and defined at the investigation area. Generally it is impermeable because of litological characteristics. Lenses of limestone karstic formations in the local aquifer characteristics have shown, even if the thrust zone is near the impermeable properties. In terms of groundwater movement in the area of these units are also considered to be barrier. That limestones is karstic where in this formation near bottom of this section which is sandstone and shale beneath. Kiyikislacik, Ekinambari and Yaykin springs come out from limestones at the investigation area (Barut, 2001) (Figure 3 $\mathrm{A}, \mathrm{B}, \mathrm{C})$.

With ophiolite group of rocks serpentinite, peridotite, gabbro, dunite and harzburgite was created with. Limitation of the study area was the eastern and southeastern. It is a hydrogeological barrier.

\section{Permeable units (Aquifers)}

The Milas Formation is made up of permeable levels of recrystalized limestones, dolomitical limestone, and marble over impermeable schists of autochthon sequence.

The mountain is in block condition and has been cut by faults. Generally, it is permeable and very karstic. Some karstic spring waters (S11 etc. in Table 1) have discharging along the impermeable schist of the contacts at the bottom of this formation. The allochthon limestones above the Gulluk Formation of the allochthon sequence are permeable limestones. The transgressive layers of Gulluk Formation are impermeable. They contain different sizes of block. Planations of discontinuite has developed inside of the grayish green recrystalized limestones. Alternating levels of calcite and dolomitical have been found to be permeable and karstic.

In the study area, limestones constitute other important aquifer allocthons, and they spread in a northwest to southeast direction. It is possible for limestones to be fed by rainwater as it creeps over them, as they spread towards southeast and contain intense karstic formations. According to the geological observations of the catchment area, although there are impermeable ophiolites on the floor, the vertical faults are in touch with the Milas limestones in some places. The movement of the groundwater in the allocthon limestones can be said to be controlled by the fracture and joint system in a northwest to southeast direction.

The Gokova Formation overlies the allochthon limestones, which has mainly occured from the layering of dolomite, dolomitical limestone, recrystalized limestone and marble. This unit have been broken, as if it has been cut often in some places by fracture, by joint, and by other discontinuities. Typically, this is attributed to karstic aquifers.

The Cirkan Formation in the basin only around Denizcik Lake and area of discharge of Beçin springs (Figure 1, section of E inside, S13) was observed (Barut, 2001). This formation is permeable and comes from the Yatagan Formation, among levels of limestone in the neuautochthon sequence. These permeable levels are rather karstic. Karstic formations have developed locally. Second porosity has been obtained transitive of tuff, of carbonate cementitous limestone, and of conglomera (with gravel from various levels). As local karstic formations were developed, secondary porosity was obtained in the transitive tuff, carbonate cementitous limestone, and conglomera (with gravel from various levels) (Barut, 2001). 


\section{Local Permeable Units}

Karstic permeability was observed where the Kalinagil Formation overlies the autochthon sequence, on levels of red limestones made of brecciaed structure, chert, and micritical limestone. Higher levels found in shale, marl, siltstone levels are impermeable. Surface of the limestone karst regions are low-level structure. In hydrogeological terms, therefore, local permeable is acceptable. The Yatagan Formation is impermeable at the neuautochthon sequence, which is coal-like and clayey in most of the sedimentary levels. The formation of the overall impervious cover local deposits. Sand and gravel which is permeable decomposed levels.

\section{Neogene Permeable Cover}

Alluvium and Slope debris; Aluvial covers are generally permeable in the coastal plain, valley bottom, and polje level bottom. But, the clay levels of the upper side are found to be impermeable aluvial sediments. Karstification was seen inside the carbonate cement of the Slope debris, as observed in the locality of the Milas-Bodrum highway. In hydrogeological respect, the formation observations of the Alluvium and Slope debris were generally accepted as permeable (Barut, 2001).

\section{Hydrogeological Circulation Model in The Investigation Area}

In the region, groundwaters run out from definite locations and mostly from the karstic spring waters that have high flow rate. While the groundwaters are fed by the rainwater filtered from the autochthon and allochthon stacking, the movement of the groundwaters is controlled by the autochthon and allochthon stacking that blocks porous carbonated rocks (and by tectonics). To the north of the catchment, the lens-like marbles existing in the schist are the feeding areas throughwhich the rainwater creeps. A run-out has happened at some locations of the spring waters with low flow rate, schist and gneisses (Barut, 2001).

In the Milas Basin spring waters/ spring water groups are four different groups; characteristics of the drilled wells in The Milas limestones are similar properties were determined to spring waters from the high-levels which is not in contact with sea water. In the case of salinity, in spring waters have occurred on deep towards the karstic levels of limestones from sea water is saturation. Examined the water was fed by a high level, the transition period is short and in aquifer in contact with shallow circulating water for a short time is. They could say that mixing different amounts of surface water were also. Given these results, the most important spring waters for the region (Savrankoy, Ekinambari, etc.,) of ground water movement in karstic system pressure and decreasing/increasing rate of interventions performed in the presence of a seawater can be mentioned.

The Milas limestone that forms the potential aquifers of the study area spreads in a wide area covering the west, the center, and the external parts of the catchment. As the Milas limestones include some karstic formations and plant cover, these understandable limitations enable the rainfall to flow and creep in high amounts. It must be taken into consideration that, the water passing through the Selimiye plain alluvions and the dudens at Karagol in the Ovakislacik plain feeds this Mesozoic limestone limitedly. Consequently, it can be said that there is an groundwater accumulation between the Polije systems in the Milas catchment and the Milas limestone. In the catchment area, the distribution of the allochthon limestones is small where the Ekinambari spring water group runs off and the water flow rate is high (Figure 3a) (Barut, 2001). For this reason, it can be explained that these spring waters are fed by rain creeps and are connected with both the allochthon limestones and the Milas limestones. 

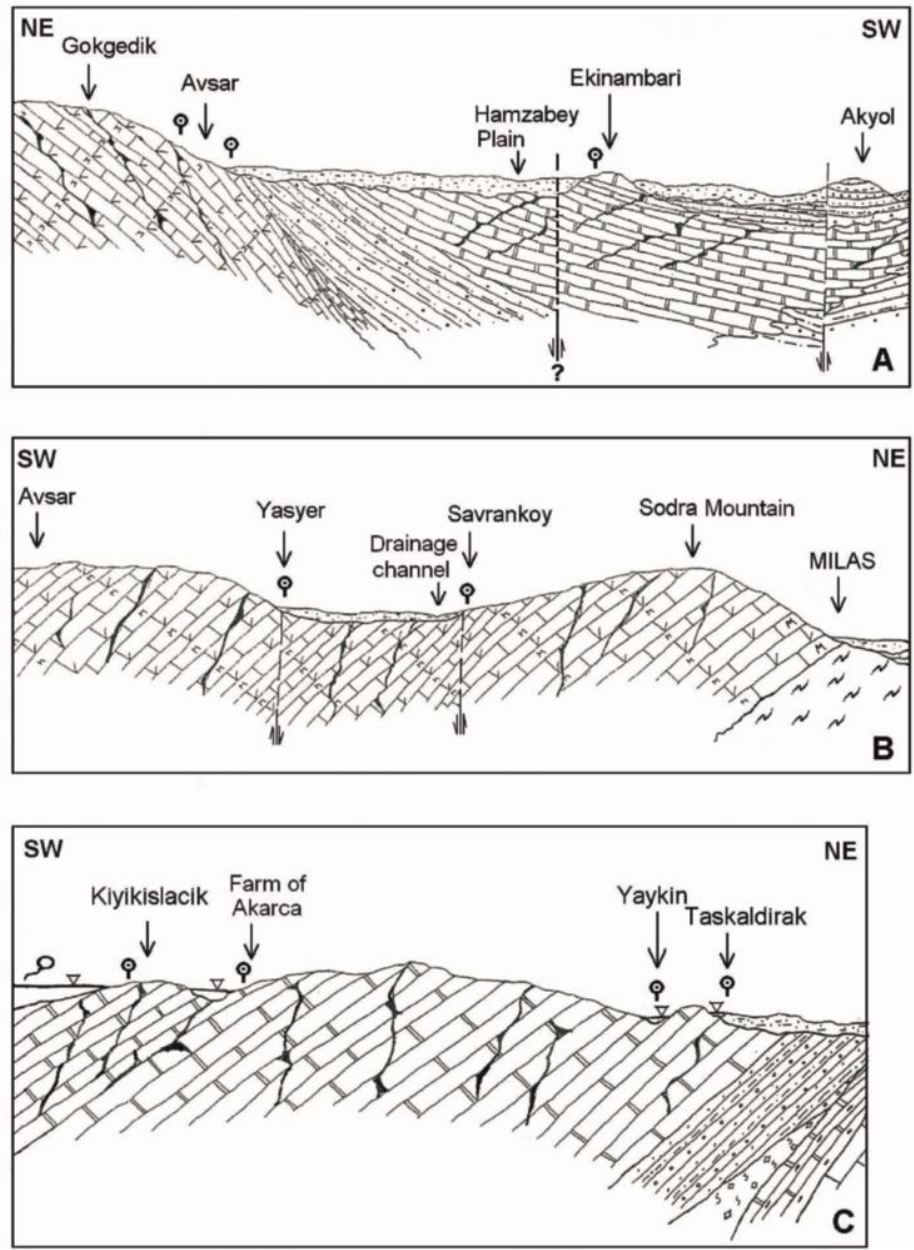

NEO-AUTOCHTHON

Quaternary $\because 0$ Aluvial

Talus slope

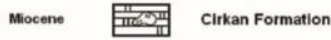

Pliocene

Yatagan Formation

AUTOCHTHON SERIE

ALLOCHTHON SERIE

Eocene
Paleocene

$5 x$ Ophiolite rocks

Mesozoic

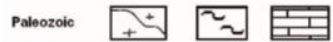

Methamorphic Base Rocks (Gneisses, Schists and Quarzites)

Gokova Formation

All Allochthon limestones

Gulluk Formation

Techtonical Melange

Fig. 3. The schematic model of runoff systems of springs groups. (A)Ekinambari springs, (B)Savrankoy springs, (C)Kiyikişlacik springs, (D)Labranda springs (Barut 2001). 
In the study area, limestones constitute other important aquifer allocthons, and they spread in a northwest to southeast direction. It is possible for limestones to be fed by rainwater as it creeps over them, as they spread towards southeast and contain intense karstic formations. The movement of the groundwater in the allocthon limestones can be said to be controlled by the fracture and joint system in a northwest to southeast direction. The feeding of the Akyol spring waters group can be explained in this way, (Figure 3a) (Barut, 2001). Although The Yatagan Formation contains widespread limestone levels, it is poor in terms of groundwaters. For this reason, it can be said that the Akyol spring water group is fed from allochthon limestones.

But, if the running out of the Sepetciler (Icme) and Savrankoy spring waters is taken into consideration, the connection of the Milas limestones, which spread under neoautochthone stacking with each other, and the highly rated running, this can be the only logical explanation. Therefore, the groundwater movement direction is from east to west at the Milas limestone. The model of Savrankoy spring waters can be clarified in this way (Figure 3b) (Barut, 2001).

The Yaykin, Taskaldirak, and Kiyikislacik spring waters group is connected with runoff from the allacthon limestones that are connected with local structures (Figure 3c) (Barut, 2001). The feeding area is from the allochthon limestones. But, the groundwater movements are developed under the control of a northwest to southeast directional overlap zone, and otocton /allochthon impermeable conglomerates.

\section{Material and Methods}

In this study, selected spring waters and drilled wells were investigated for hydrogeologic conditions. Distribution of water sampling points is shown in Figure 1, Table 1. Investigations of samples were taken as the basis of calendar at hydrological timing during different periods (between March/1996 and November/1998, April 2007, October 2008). Collectively, in the process studies involve 17 spring groups, 38 drilling wells, 1 stream, 2 lakes, and seawaters of the Gulluk and Milas (Meteorological Observation Station) $7 \mathrm{~km}$ eastern of the Kozagac (Meteorological Observation Station) area. DSI is a concern that the findings in this study are evaluated together with our findings of our study.

The measurements were produced in area parameters which flow (1/s), electrical conductivity (EC), total dissolved solid contents (TDS), salinity (S\%o), hydrogen ion concentrations $(\mathrm{pH})$, and temperature $\left({ }^{\circ} \mathrm{C}\right)$ for preliminary hydrogeological evaluation and seasonal variation every three months. The parameters in spring waters/wells of water samples at the area/laboratory measurement techniques and measurement sensitivity was determined that: physical parameters such as temperature $\left({ }^{\circ} \mathrm{C}\right), \mathrm{pH}$, salinity $(\mathrm{S} \%$ o) and electrical conductivity (EC) were measured during fieldwork in the point of spring water by instruments. Temperature with measurement sensitivity $\left( \pm 0.1^{\circ} \mathrm{C}\right)$ by water thermometer. Measurements of $\mathrm{pH}$ were made by $\mathrm{pH}$ meter by NEL PH900 Model pH meter with measurement sensitivity $\pm 0.001 \mathrm{pH}$. EC of samples was measured by ORION Model 105 SCT meter with measurement sensitivity $\pm 1 \%$. Salinity $( \pm 1 \%)$ and temperature values were also checked with the same instrument.

Regarding the physical and chemical analyses, all samples (except one) were sampled on the basis of APHA, 1992 sampling methods. The chemical compositions in water samples of anion and cation were determined in the laboratory of Istanbul University, Faculty of Engineering. The standard deviation of samples is $\pm \% 1$ in chemical analyses. Some cations of $\mathrm{Na} \%$ and $\mathrm{K} \%$ have been been measured analyses concentrations by Flame Photometer (DRB-Lange Berlin M6a) with measurement sensitivity $\pm 1 \%$. $\mathrm{Sr}^{2+}$ were analyzed using Atomic absorption spectrophotometry (Rank Hilger Atomspek H1550) with measurement sensitivity $\pm 0.001 \mathrm{mg} / \mathrm{l}$. Analyses of $\mathrm{B}^{3+}$ and $\mathrm{I}^{-}$ concentrations were analyzed using Spectrophotometry (ATI-UNICAM UV/VIS Spetrometer UV2) with measurement sensitivity $\pm 0.001 \mathrm{mg} / \mathrm{l}$. And for $\mathrm{F}^{-}( \pm \%$ 1) using by Ion selector (Jenway 3040 Ion Analysor). The major anion and cation analyses $\mathrm{Ca}, \mathrm{Mg}, \mathrm{HCO}_{3}, \mathrm{CO}_{3}, \mathrm{Cl}, \mathrm{SO}_{4}$ were analyzed 
through by the volumetric titration (\%) and measurement sensitivity $1 \%$. Total Hardness titration method was measured in the laboratory with measurement sensitivity $( \pm \% 1)$. The chemical compositions in water samples of anion and cation were determined in the laboratory of Istanbul University, Faculty of Engineering. The result of chemical analyses of DSI (General Directorate of State Hydrolic Works) datas of groundwater, precipitation and seawater; with precipitation and seawater datas from Kurttas (1997), were considered as well.

For isotope sampling and analysis an important principle was followed which involved the use of two sampling times, after dry and wet period. Through the application of isotope subsidence of the valleys has resulted in the rather thick sedimentation in the Neogene and analyses of ${ }^{18} \mathrm{O}, \quad{ }^{2} \mathrm{H}, \quad \mathrm{T}$ three samples were studied (involving Yasyer, Ovakislacik and Avsar spring waters). Analyses were conducted in this study at the DSI-Research Department Isotope Laboratory in May 1998, April 2007 and October 2008. In the DSI Karst Department research has been continued based on isotopical hydrologic study findings within the same investigation area or zone. Karst hydrogeological studies have been completed observing common research protocol between DSI and IAEA. Stable isotopes $\left(\delta^{2} \mathrm{H}\right.$ and $\left.\delta^{18} \mathrm{O}\right)$ were analysed using an isotopic liquid water and vapour water analyser (DUAL INLET IRMS (Isotope Ratio Mass Spectrometer) at the DSI-Research Department Isotope Laboratory. Stable isotopic compositions are reported in the usual $\delta$ notation, in which $\delta$ is equal to (Rsample/Rstandard - 1) $\times 1000$, where Rsample and Rstandard represent the ratio of heavy to light isotopes of the sample and standard, respectively. The measurement of the

\section{Results}

Water types and diagrams

Water temperatures of spring water and well waters are between $15-23^{\circ} \mathrm{C}$ (Table 1). The results of periodically repeated analysis chemical concentrations values increased compared with which between 1996-1998, April 2007, October 2008. The some concentrations $\left(\mathrm{Na}, \mathrm{K}, \mathrm{Cl}, \mathrm{SO}_{4}\right)$ which in October 2008 karstic spring waters contained concentration of tritium liquid scintillation counting was done by counting techniques at the water samples. Measurements at very low levels capable of counting Perkin-Elmer Quantulus Ultra Low Level Liquid Scintillation device was used.

Saturation indices and ionic findings were calculated to better understand the hydrogeochemical processes that take place in the aquifer. Calculation of the ionic deltas $(\Delta)$ consists of a comparison of the actual concentration of each constituent with its theoretical concentration for a freshwaterseawater mix calculated from the $\mathrm{Cl}$ concentration of the sample (Appelo and Postma, 1994): $\Delta \mathrm{C}_{\mathrm{i}}=\mathrm{C}_{\text {isample }}-\mathrm{C}_{\text {imix }}$; where $\Delta \mathrm{Ci}$ is the ionic delta of the ion $i, \mathrm{C}_{\text {isample }}$ is the measured concentration of the ion $\mathrm{i}$ in the sample, and $\mathrm{C}_{\text {imix }}$ is the theoretical concentration of the ion $i$ for the conservative mix of freshwater and seawater. The theoretical mix concentration was calculated by reckoning the seawater contribution from the sample $\mathrm{Cl}$ concentration $\left(\mathrm{C}_{\mathrm{Cl} \text {,sample }}\right)$, the freshwater $\mathrm{Cl}$ concentration $\left(\mathrm{C}_{\mathrm{Cl}, \mathrm{f}}\right)$ and the seawater $\mathrm{Cl}$ concentration $\left(\mathrm{C}_{\mathrm{Cl}, \text { sea }}\right)$ :

$f_{\text {sea }}=\left(\mathrm{C}_{\mathrm{Cl}, \text { sample }}-\mathrm{C}_{\mathrm{Cl}, \mathrm{f}}\right) /\left(\mathrm{C}_{\mathrm{Cl}, \text { sea }}-\mathrm{C}_{\mathrm{Cl}, \mathrm{f}}\right)$

This seawater contribution was used for calculating the theoretical concentration of each ion:

$\mathrm{C}_{\mathrm{i}, \text { mix }}=f_{\text {sea }} \cdot \mathrm{C}_{\mathrm{i}, \text { sea }}+\left(1-f_{\text {sea }}\right)-\mathrm{C}_{\mathrm{i}, \mathrm{f}}$

These calculations can be made because $\mathrm{Cl}$ can be considered as a conservative tracer: the only inputs are from the salts in the aquifer matrix itself or from a salinization source, and it is not usually removed from the system due to its high solubility (Appelo and Postma, 1994).

were increased which of Avsar, Ekinambarı, Savranköy, Sepetciler, and also Çınarkaynak spring water (Fig. 1; section of D inside, S04, S05, S06, S11).

In seasonal variations of groundwaters Hydrogen Ion Concentrations ( $\mathrm{pH})$ concentrations are between $\mathrm{pH}=6.5-8.4$ based on measurements taken from the head of spring waters at the study area (Table 1) 


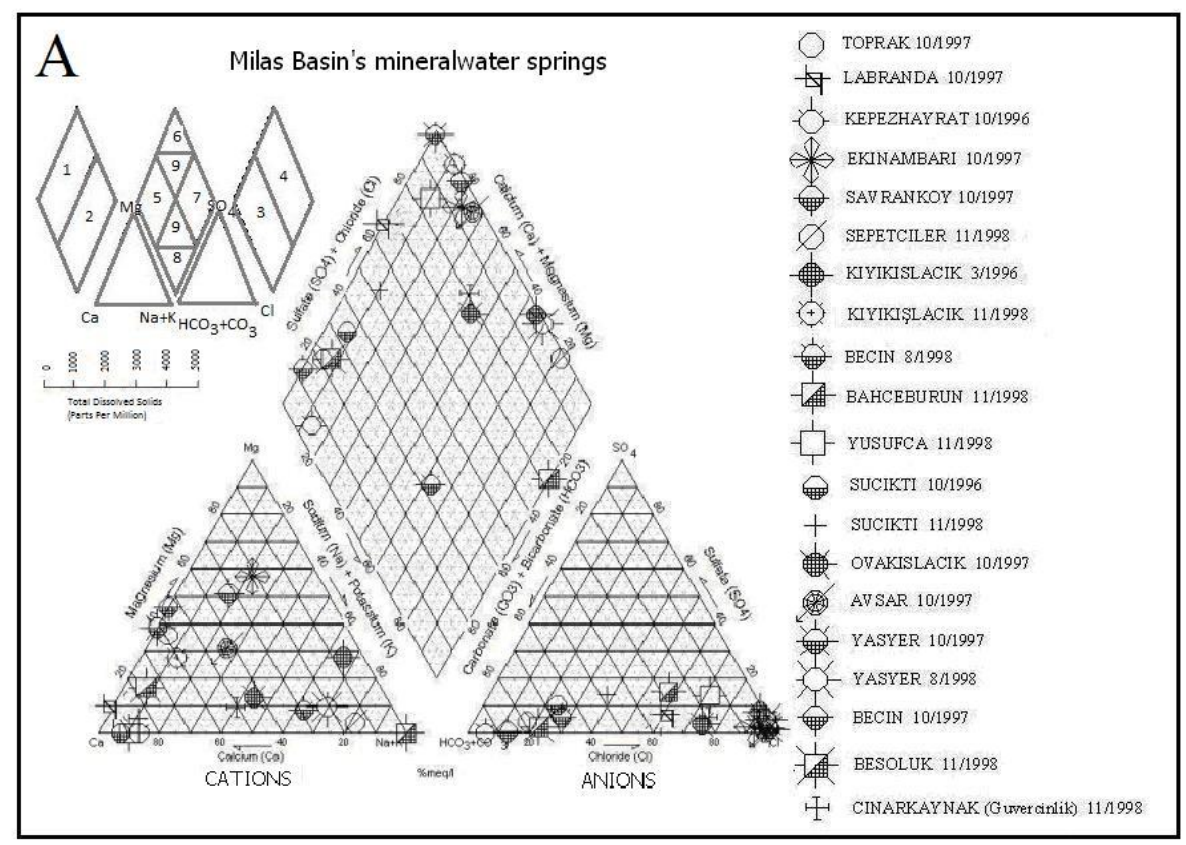

Fig 4a. Piper diagram (in meq/l) showing major-ion composition of spring waters.

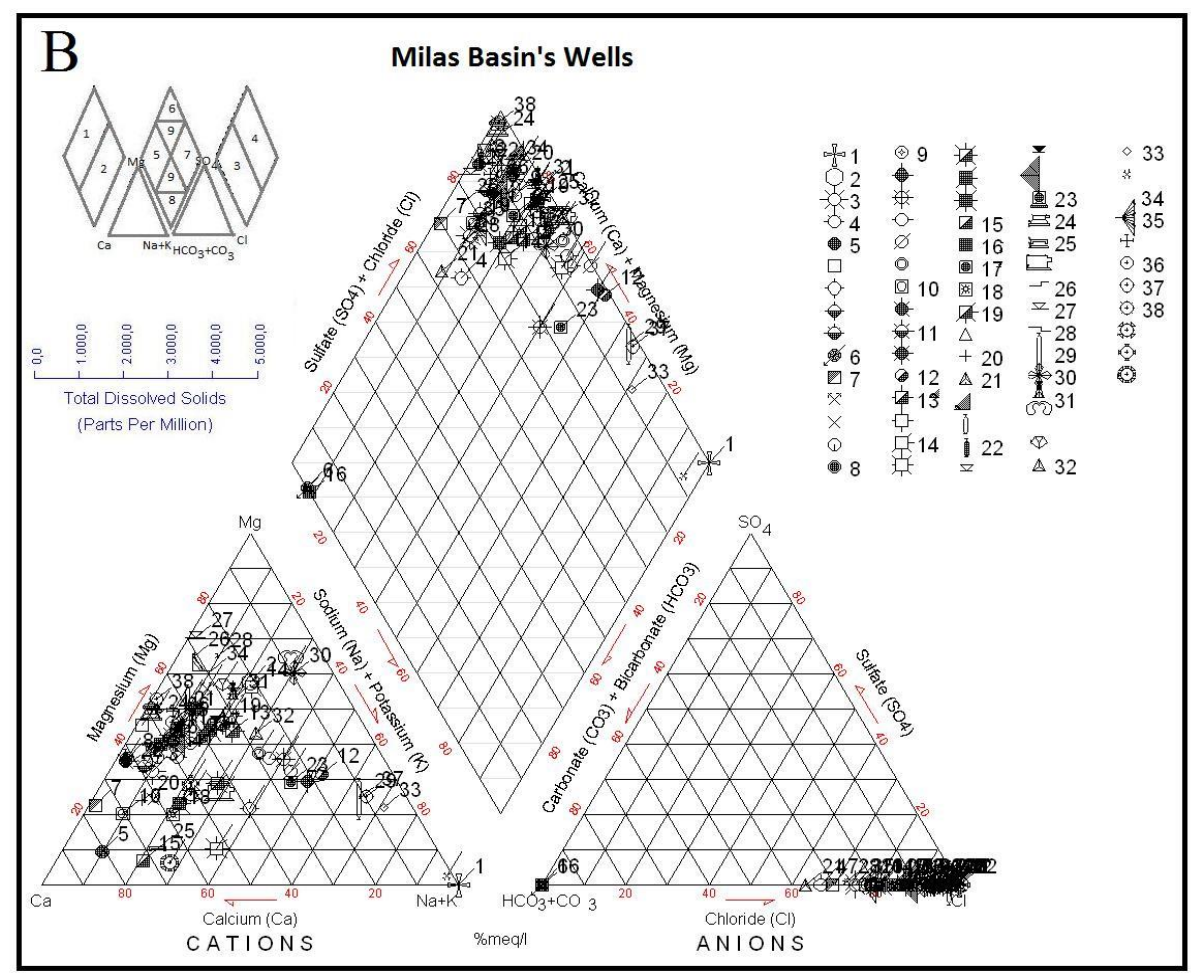

Fig.4b. Piper diagram (in meq/l) showing major-ion composition of wells.. 
Table 1 The hydrological characteristics of spring water in the investigated area.

\begin{tabular}{|c|c|c|c|c|c|c|c|c|c|}
\hline & Springs group & $\begin{array}{l}\text { Altitude } \\
\text { (m) }\end{array}$ & 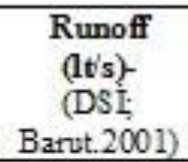 & 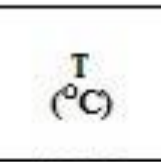 & $\begin{array}{c}\text { EC } \\
\text { (meros } / \mathrm{cm} \text { ) }\end{array}$ & $\% \circ \mathrm{S}$ & $\begin{array}{l}\text { Total } \\
\text { Min. } \\
\text { mg/1 }\end{array}$ & $\mathrm{pH}$ & $\begin{array}{c}\text { Type } \\
\text { Cold groundwater }\end{array}$ \\
\hline $\mathrm{SO1}$ & Toprak & 330 & $4-6$ & $19-23$ & $435-600$ & $0.9-1.5$ & 577 & 7.4 & $\mathrm{Ca}$ F. $\left(\mathrm{HCO}_{3}\right) \cdot \mathrm{Sr}$ \\
\hline $\mathrm{SO} 2$ & Labranda & 1000 & 24 & 15 & 500 & 0 & 64.8 & 7.1 & $\mathrm{Mg} .\left(\mathrm{HCO}_{4}\right)$ \\
\hline $\mathrm{S} 03$ & Kepezhayrat & 200 & $0.5-1$ & $16.5-19.4$ & 3000 & 0.6 & 640 & 7 & $\mathrm{Mg} .\left(\mathrm{HCO}_{1}\right)$ \\
\hline \$04 & Ekinambari & $10-50$ & $6-10$ & 17 & $7500-14000$ & 7.5 & 4000 & 7.5 & $\mathrm{Na} . \mathrm{Cl} .\left(\mathrm{HCO}_{3}\right)$ \\
\hline S05 & Savrankoy & 10 & $4-5$ & 19 & 15000 & $10-19$ & 9000 & 7.8 & $\mathrm{Na} . \mathrm{Cl} .\left(\mathrm{HCO}_{2}\right)$ \\
\hline$\$ 06$ & Sepetciler & $20-50$ & $3-5$ & 20 & 18000 & 18 & 15093 & 7.6 & Na. Cl. $\left(\mathrm{HCO}_{2}\right)$ \\
\hline S07 & Akarca (Kiyikislacik) & $0-10$ & $5-10$ & 16 & $7000-14000$ & 25 & 16265 & 7 & $\mathrm{Ca} \cdot \mathrm{Cl} \cdot\left(\mathrm{SO}_{4}\right)$ \\
\hline So8 & Yusufca & 236 & $5-6$ & 16 & 700 & 1.9 & 1600 & 7 & $\mathrm{Ca} . \mathrm{Cl} .\left(\mathrm{HCO}_{3}\right)$. I \\
\hline$\$ 09$ & Ovakislacik & 20 & 2.5 & 16 & 1000 & $1.5-3.5$ & 1500 & 7.5 & Na. Cl. $\left(\mathrm{HCO}_{2}\right)$ \\
\hline \multirow[t]{2}{*}{$\$ 10$} & Sucikti & 95 & $10-12$ & 15 & 600 & 0.5 & 400 & 7.2 & $\mathrm{Mg} \cdot\left(\mathrm{HCO}_{3}\right)$ \\
\hline & Akyol & 20 & $1-5$ & 17.5 & $9000-10000$ & 15 & & 7.5 & $\mathrm{Na} \cdot \mathrm{Cl} \cdot\left(\mathrm{HCO}_{3}\right)$ \\
\hline \multirow[t]{2}{*}{ \$11 } & Avsar (Gumbuldek) & 10 & $0.5-1$ & 18 & $7000-14000$ & 10 & 4800 & 7.8 & Na. Cl. $\left(\mathrm{HCO}_{1}\right)$ \\
\hline & Yaykin L. & $\sim 0$ & 1.5 & 19 & 20000 & 23 & & 8 & $\mathrm{Ca} \cdot \mathrm{Cl} \cdot\left(\mathrm{SO}_{4}\right)$ \\
\hline$\$ 12$ & Yasyer & 20 & 1 & 18 & 5000 & 12 & 16050 & 7.8 & $\mathrm{Ca} \cdot \mathrm{Cl} \cdot\left(\mathrm{SO}_{4}\right)$ \\
\hline$\$ 13$ & Becin & 200 & $0.5-1$ & $16.5-19.4$ & 3200 & 0.6 & 640 & 7 & $\mathrm{Mg} \cdot\left(\mathrm{HCO}_{1}\right)$ \\
\hline$\$ 14$ & Bahçeburun & $200-1000$ & 2.4 & 18.4 & 500 & 1.1 & 1995 & 7.2 & $\mathrm{Mg} .\left(\mathrm{HCO}_{3}\right)$ \\
\hline$\$ 15$ & Besolvk & 619 & $15-20$ & 15 & 350 & 0 & 1000 & 7.1 & $\mathrm{Ca} \cdot\left(\mathrm{HCO}_{3}\right) \cdot \mathrm{Fl}$ \\
\hline$\$ 16$ & Karaagac & 630 & $9-12$ & 15 & 350 & 0 & 1250 & 7 & $\mathrm{Na} \cdot\left(\mathrm{HCO}_{3}\right) \cdot \mathrm{FI}$ \\
\hline \$17 & Cinatkaynak (Guvercinlik) & 0 & 24 & 19.5 & 239 & 0.9 & 1100 & 7.6 & Cl. F \\
\hline
\end{tabular}


Table 2. The average contribution rates of seawater in the spring waters and representative

\begin{tabular}{|c|c|c|c|c|}
\hline & ID sample & $\begin{array}{c}\text { Rate of contribution } \\
\text { seawater }(\%)\end{array}$ & $\begin{array}{c}\text { Distance of } \\
\text { seashore }(\mathbf{k m})\end{array}$ & $\begin{array}{c}\mathrm{Cl} \\
\mathrm{meq} / \mathrm{l}\end{array}$ \\
\hline \multirow{10}{*}{ Spring water } & S04 & 13 & 8.84 & 78 \\
\hline & S05 & 35 & 11.73 & 281 \\
\hline & S06 & 37 & 11.44 & 198 \\
\hline & S07 & 49 & 0.1 & 358 \\
\hline & S08 & & 19.77 & 4.2 \\
\hline & S09 & 2 & 9.63 & 32 \\
\hline & S11 & 13 & 5.33 & 94 \\
\hline & S12 & 31 & 8.82 & 220 \\
\hline & S14 & & 19.24 & 9.5 \\
\hline & S17 & 1 & 0 & 10 \\
\hline \multirow{8}{*}{ Wells } & 1 & 13 & 6.23 & 67.4 \\
\hline & 9 & 3 & 7.7 & 15.1 \\
\hline & 29 & 8 & 7.84 & 41 \\
\hline & 16 & 2 & 9 & 8.3 \\
\hline & 30 & 5 & 9.12 & 23 \\
\hline & 31 & 2 & 9.85 & 8 \\
\hline & 13 & 2 & 11.22 & 9.4 \\
\hline & 3 & 6 & 16.5 & 28.4 \\
\hline
\end{tabular}

Alkalinity, In water samples taken for analyses in August $/ 1998$, waters were determined to have low values (between of 1.54-6.06 meq/l) in seasonal variation. Investigation. Groundwater in the study area is not in the acidic properties.

Percentages of sodium (\% Na) growth in irrigation waters have caused variations to occur in calcium and magnesium levels within the soil. The value of $\% \mathrm{Na}$ was calculated to be between 19.6-86.2. The value of SAR was calculated on a scale between 1-33 in the study area. High EC values were measured between 7501-17310 micromho/cm for Ekinambari, Savrankoy, Sepetciler (Icme), Avsar, Kiyikislacik and Dalyan. The value of EC was between $946-7500$ micromho/cm at the Selimiye plain. The high TDS content of these mineralwaters is also well correlated with the high EC values (Table 1)

Spring waters: General distribution of groundwaters is shown on a Piper diagram (Piper, 1953), (Figure 4a). On the basis of this diagram: characteristics of Toprak, Labranda,
Sucikti and Becin spring waters (as runoff in high altitude).

$\mathrm{Mg}^{2+}>\mathrm{Ca}^{2+}>\mathrm{Na}^{+}+\mathrm{K}^{+} ; \mathrm{HCO}_{3}{ }^{-}+\mathrm{CO}_{3}{ }^{2-}>\mathrm{Cl}^{-}$ $>\mathrm{SO}_{4}{ }^{2-} ; \mathrm{EC}=450-800$ micromho/cm Characteristics of Ekinambari, Savrankoy, Akyol, Kiyikislacik and Yaykin group.

$\mathrm{Na}^{+}+\mathrm{K}^{+}>\mathrm{Mg}^{2+}>\mathrm{Ca}^{2+} ; \mathrm{Cl}^{-}>\mathrm{SO}_{4}{ }^{2-}>\mathrm{HCO}_{3}{ }^{-}$ $+\mathrm{CO}_{3}{ }^{-} ; \mathrm{EC} \sim 3500$ micromho/cm

Groundwater samples were determined in four different four groups.

1) $\mathrm{Mg},\left(\mathrm{HCO}_{3}\right)$; Spring waters of $\mathrm{S} 01, \mathrm{~S} 02$, S03,S10, S13

2) $\mathrm{Na}, \mathrm{Cl},\left(\mathrm{HCO}_{3}\right)$; Spring waters of $\mathrm{S} 04, \mathrm{~S} 05$, S06, S09, S11, Akyol.

3) $\mathrm{Ca}, \mathrm{Cl},\left(\mathrm{SO}_{4}\right)$; Spring waters of $\mathrm{S} 07, \mathrm{~S} 08$, S12.

4) $\mathrm{Cl}, \mathrm{F} ; \mathrm{S} 14$

Drilling wells: (Figure 4b)

$\mathrm{Ca}^{2+}+\mathrm{Mg}^{2+}>\mathrm{Na}^{+}+\mathrm{K}^{+} ; \mathrm{HCO}_{3}{ }^{-}+\mathrm{CO}_{3}{ }^{2-}>\mathrm{Cl}^{-}$ $>\mathrm{SO}_{4}{ }^{2-}$

All groundwaters are evaluated from the chemical analyses results of DSI drilling wells, that wells on Milas limestones don't make contact with seawater. The spring waters, which run-off at high altitude, are assigned a similar classification. 


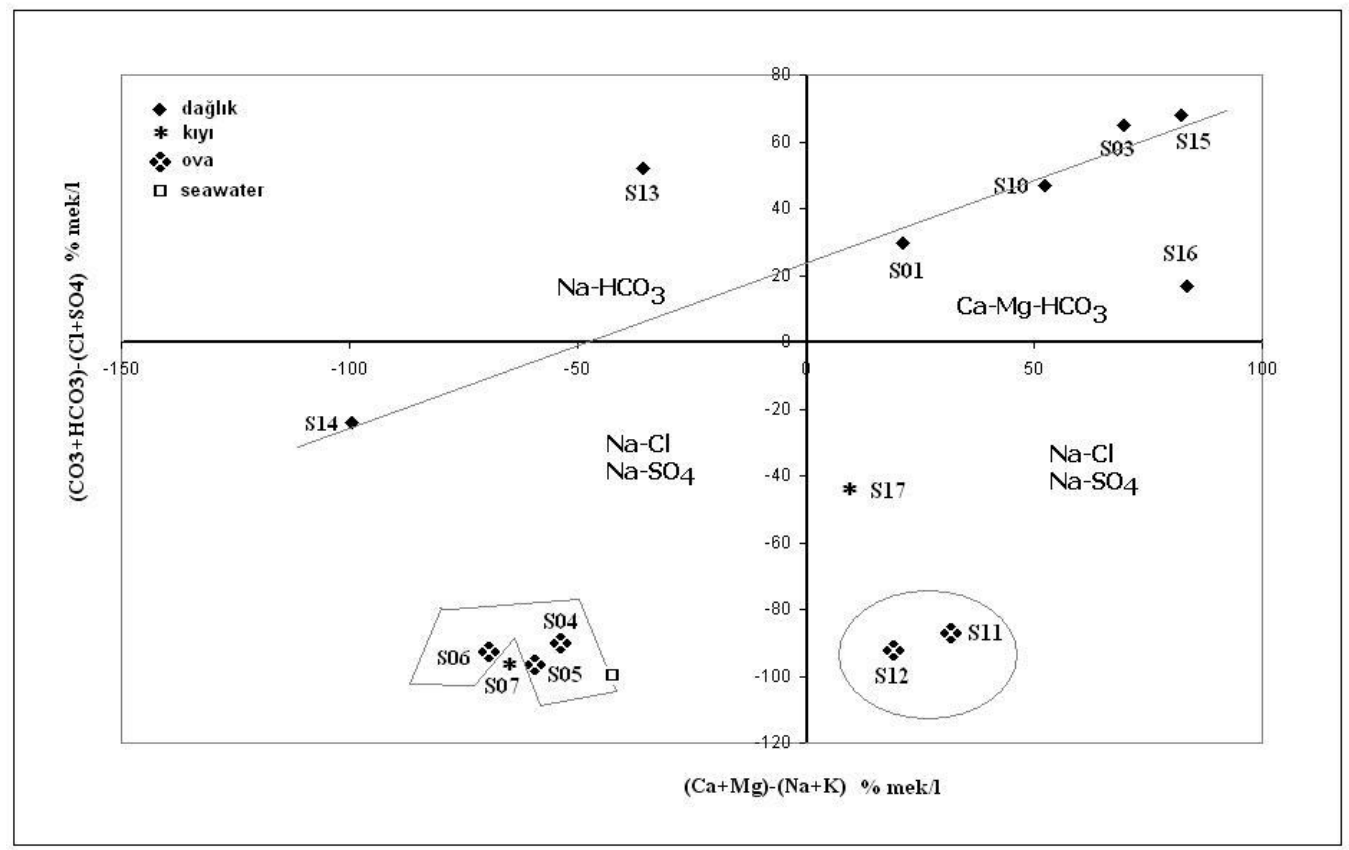

Fig. 5. Chadha diagram (in meq/l) showing major-ion composition of spring waters.

In this study, surface and ground waters to classify and define the functions of hydrogeochemical Chadha diagram (Chadha 1999) were used (Figure 5). According to the chemical components of the mountainous part of $\mathrm{Ca}-\mathrm{Mg}-\mathrm{HCO}_{3}$ water type. This type of water, dissolved in water can be interpreted as the first step of the water-rock association, which also explains the presence in the basin of marble. And in this context does not provide a proper cluster parts of the coastal waters of the inland towards the coast, respectively, $\mathrm{Na}-\mathrm{Cl} / \mathrm{Na}-\mathrm{SO}_{4}$, $\mathrm{Ca}-\mathrm{Mg}-\mathrm{SO}_{4}-\mathrm{Ca}-\mathrm{Mg}-\mathrm{Cl}$ and $\mathrm{Ca}-\mathrm{Mg}-\mathrm{HCO}_{3}$ type, offer a feature.

Origin saliniy of groundwaters with isotopic and hdrogeochemical data Saturation indices (SI) of waters with respect to calcite (Sc) and sulfate (Ss) were computed using the relevant thermodynamic equations. Saturation analysis were computed and evaluated at representative wells $(5,8,9,15,17,18,23,24,25,31,32,33$, 36,38 ) (Figure 1) for areas of hydrological investigation in 1991. Observation supports that saturation analysis are probably seasonal. At Sc-Sd (Figure 6), it was also observed that there is a linear relationship between calcite values and dolomite. In the groundwater has a high saturation index. Sc-Ss a relationship is shown based on the increase of calcite values along with the sulfate saturation values.

Sulfate saturation values are highest, which explains the belief that waters from the Milas limestones and at eastern and southern Sodra Mountain drillingwells have a relationship or shared connection with gypsum-bearing units. Low Ss saturation levels occured at the eastern Sodra Mountain location, where Kaymakkavagi and Milas Plain are northern of the plain. The fact that the Ss saturation levels are relatively low can be an indicator that the alimentation by alluvium has occured, and that these waters are mixing with waters from that alluvium. Considering the EC-pH relation, it can be said that the groundwater is saturated with respect to calcite, and it has also mixed with the alluvium waters. If geochemical conditions are favorable, waters in the region can precipitate the calcite and sulfate. The saturation order for the waters is recorded as Sc $>$ Ss (Barut, 2001).

In the pH-EC- $\mathrm{P}_{\mathrm{CO} 2}$ high values of $\mathrm{EC}$ and $\mathrm{P}_{\mathrm{CO} 2}$ were observed to be due to the linear relationship of the waters. The $\mathrm{pH}$ of groundwaters indicates that they are the most effected and changed by the balance of $\mathrm{CO}_{2}$ by $\mathrm{CO}_{3}+\mathrm{HCO}_{3}$. The ability of $\mathrm{CO}_{2}$ gases to 
dissolve in water does appear to be related to pressure and temperature. Therefore $\mathrm{Ca}$ ions tend to increase with the increase of $\mathrm{CO}_{2}$ if the environment isn't chemically balanced. This explains the high concentrations of $\mathrm{CO}_{2}$ in the environment. Considering the $\mathrm{pH}-\mathrm{EC}$ by $\mathrm{pH}$ $\mathrm{P}_{\mathrm{CO} 2}$ relationship when evaluated together, it can be said that the groundwaters are saturated with respect to calcite, and these waters have mixed with the alluvium waters (Barut, 2001).

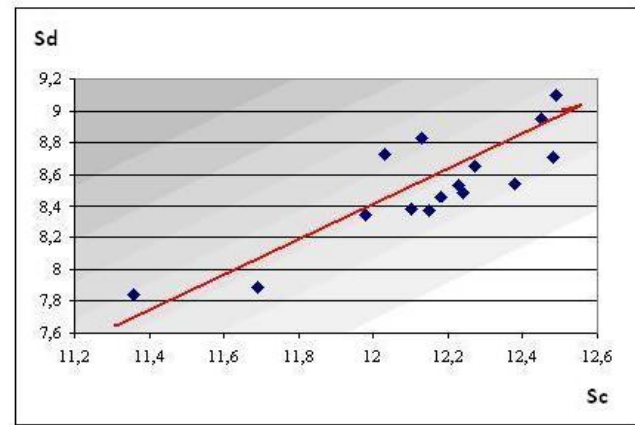

Fig.6. Linear relationship between calcite values and dolomite $(\mathrm{Sc}-\mathrm{Sd})$ in drilling wells.

If groundwater saturated with carbondioxide exits the ground's surface through drillingwells or spring waters, the $\mathrm{CO}_{2}$ concentration begins to lessen. Groundwater solubility is related to $\mathrm{CO}_{2}$ concentration. Generally, the description of water according to $\mathrm{pH}$ is distinctive to the ions of $\mathrm{H}_{2} \mathrm{CO}_{3}$ (carbonic acid) if the water is acidic, $\mathrm{HCO}_{3}$ if the water is neutral, and $\mathrm{CO}_{3}$ if the water is basic. Some water, until carbonation is balanced, does continue to dissolve carbonate. When mineral concentrations in water are being dissolved there is a decrease in water solubility, and some water will become saturated with carbonate. All groundwaters at the investigation area, according to laboratory conditions, have been saturated by calcite dolomite. Therefore, research findings support the strong presence of carbonate minerals, mainly calcite and dolomite on the larger scale. The saturation indices of values are categorized according to condition: as low-satisfied (if negative), or very highsatisfied (if positive). The order of saturation at the investigation area is characterized as Sc $>$ Sd $>$ Ss (Barut, 2001).

Seawater into coastal spring waters in the study area with an assessment technique for the determination of the contribution rate has been applied. Precipitation, seawater and $\mathrm{Cl}$ belong to the relevant sample points, and such as ${ }^{18} \mathrm{O}$ content parameters were utilized. The two ends of the component mixture of hydrogeochemical resulting mixture at the end in water volumetric ratios of the components are considered (Appelo and Postma, 1994). Again with $\mathrm{Cl}$ ion forming salinity $\mathrm{I}, \mathrm{Br}, \mathrm{Mg}, \mathrm{SO}_{4}$ ions is required to have high values. Salinity from of the sea that came together to support the evaluation of these indicators are important. Groundwater ions ratio close to the ratio of ions in seawater of salinity seawater is considered to have come.

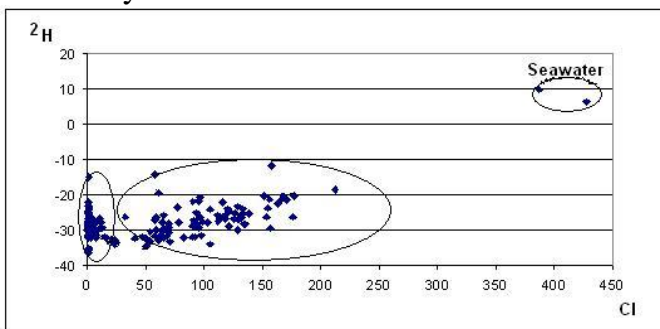

2

Fig.7. Cl- $\mathrm{H}$ to establish relations of wells and water springs at investigation area.

Wherein the representative instance seawater, freshwater precipitation mixture and current is not influenced Gulluk seawater samples were used. Representative freshwater $\mathrm{Cl}$ content of seawater is accurate determination of the contribution rates to be calculated correctly is also important. Seawater contribution in the calculation of non-saline groundwater $\mathrm{Cl}$ concentration, the shallow circulation and a large percentage of annual rainfall fed with spring waters (S01, S02, Karaagac, Besoluk) average $\mathrm{Cl}$ concentration (in 5 field study average of: $0.775 \mathrm{mmol} / \mathrm{l}$ ) and seawater $\mathrm{Cl}$ content $(540 \mathrm{mmol} / \mathrm{l})$ is taken as. In the equation water samples $\mathrm{Cl}$ content calculated and seawater contribution rate were determined seawater

contribution $(\%)=\mathrm{Cl}$ sample spring $(\mathrm{mmol} / \mathrm{l})-\mathrm{Cl}$ non-saline spring $(\mathrm{mmol} / \mathrm{l}) / \mathrm{Cl}_{\text {seawater }}(\mathrm{mmol} / \mathrm{l})-\mathrm{Cl}$ non-saline spring $(\mathrm{mmol} / \mathrm{l})$. As seen in the examples is the average value of $1-49 \%$ (Table 2).

The difference in (pH-pHs) levels and $\mathrm{SI}$ is explained by the evidence of ions at the surrounding area which are higher in value than those calculated for $\mathrm{pH}$ values. This explains the high concentrations of $\mathrm{CO}_{3}$ and $\mathrm{HCO}_{3}$ in the environment, and the formation of $\mathrm{CO}_{2}$ by $\mathrm{CO}_{3}$ 
and $\mathrm{HCO}_{3}$, changing the acidical and basical properties. This difference can be explained by temperature, and the contact time with $\mathrm{O}_{2}$ due to the effect of other ions. This result supports that alimentation of the system occurs at a high level (wells numbered 8-9-15-18-24; in Figure 1 , section $\mathrm{D}$ and $\mathrm{E}$ inside). SI positive values are indicators of a $\mathrm{CO}_{3}$ increase. The general classification of rocks is evaluated as the rocks with $\mathrm{CO}_{3}$. SI negative waters indicate that the groundwaters (as in, well-17; Figure 1, section D inside) are affected by the acidical properties of their environment. The groundwaters are contact with rocks containing $\mathrm{SO}_{4}$. The environment of this is characterized by gypsum and epsomite.

The difference in terms of ${ }^{2} \mathrm{H}$ is observed in $\mathrm{Cl}$ and $\mathrm{SO}_{4}$ stability. This shows that the feeding altitudes are different and can be explained by the winter and summer rainfall differences. No correlation in ${ }^{2} \mathrm{H}-\mathrm{HCO}_{3}$ relations was observed. If the $\mathrm{EC}^{2} \mathrm{H}$ relation is examined, it is seen that there is no linearity except among the S04, S07, S11 spring waters. This correlation can be explained by the similar characteristics of the feeding waters. The $\mathrm{Cl}-{ }^{2} \mathrm{H}$ relation supports that the $\mathrm{Cl}$ content in these waters is from the same origin (Barut, 2001).

The $\mathrm{Cl}-{ }^{2} \mathrm{H}$ relationship (Figure 7), in terms of ${ }^{2} \mathrm{H}$ enrichment in $\mathrm{Cl}$ constant value under the influence of the height differences of the different rainfall (Kozağaç, Milas, etc.) can be explained by the nourishment. The catchment has been evaluated concerning the effect of altitude and by the different rains (Milas and Kozagac etc.). Direct and indirect nourishment area is an important problem for the investigation of surface areas which are semiarid. The values of concentrations ${ }^{3} \mathrm{H}$ at wells shows that nourishment regions have been affected by the rainfall. The ${ }^{3} \mathrm{H}$ content at the surface of the open wells in some conditions over time have changed as a result of interaction with the atmospheric vapor.

The relation of $\delta^{2} \mathrm{H}-\delta^{18} \mathrm{O}$ for the S04, S05 and S06 spring waters is the same in regards to typical rainfalls, but nourishment by the location of these springs to springs at coast springs of S07 (because of their proximity to the Milas rain line) is expressed as $\delta$
${ }^{2} \mathrm{H}=7.75 \delta{ }^{18} \mathrm{O}+13.65$. Milas rainfalls are effective at the nourishment area for the S07 springs.

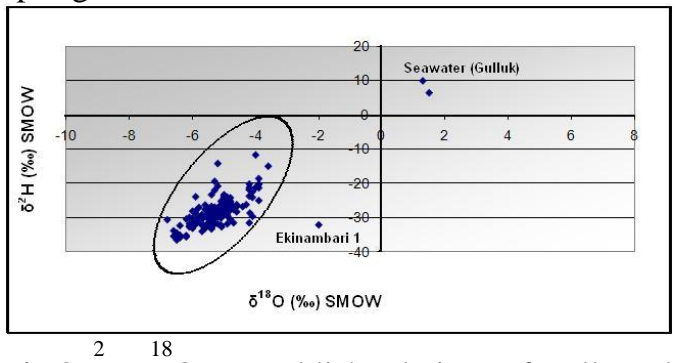

Fig.8. ${ }^{2} \mathrm{H}-\mathrm{O}$ to establish relations of wells and springs at investigation area.

The nourishment area of the S04, S05 and S06 spring waters has been determined based on the rate of the mixture of the waters. The spring waters of the investigation area with a ${ }^{18} \mathrm{O}-{ }^{2} \mathrm{H}$ relation have been observed between the seawater and the terrestrial Craig (1961) line (Figure 8). However, for spring waters in the Zone A (Figure 1) the outside 2 lines of data appear to acknowledge presence of seawater mixtures. If this has been observed in samples with a density of $\mathrm{EC}-{ }^{18} \mathrm{O}$, the relation is explained by the effect of evaporation. The diagram of $\mathrm{EC}^{-18} \mathrm{O}$ point of $\mathrm{EC}=0$ indicates that there has been a wash of salty formations, and meteoric waters have been added into the water system from catchment areas (Figure 9).

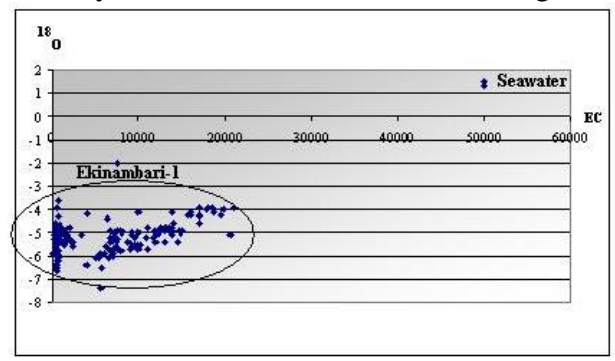

Fig.9. EC - ${ }^{18} \mathrm{O}$ to establish relations of wells and water springs at investigation area.

In the course of time, this results due to the effected of atmospheric evaporation. Within the scope of this study, ${ }^{3} \mathrm{H}$ content levels were measured as $\sim 5 \mathrm{TU}$ at the S11 and S12 spring waters, and this value is related to the ${ }^{3} \mathrm{H}$ content level measured at the Muhal Sea? (Figure 1). Water mixture studies were on an evident range and are determinate actual (before the nuclear tests of rainfall). 


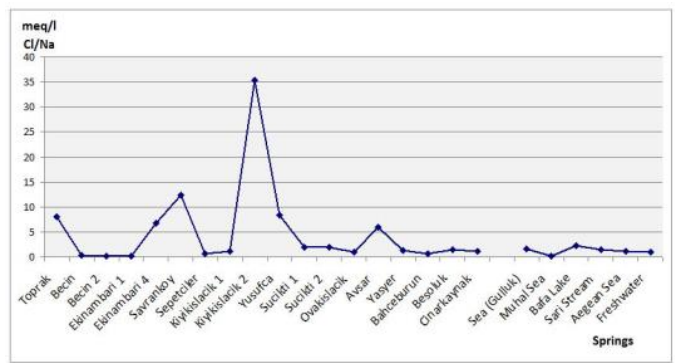

Fig. 10. Distribution of $\mathrm{Cl} / \mathrm{Na}$ ratios of spring waters, lake, stream and sea (Gulluk) at investigation area.

According to the classifications of Hem 1965, at waters range of $\mathrm{Cl} / \mathrm{Na}$ molarity $>1$ (reciprocal interaction of from evaporate rocks), range of $\mathrm{Cl} / \mathrm{Na}<1$ (mixture fossil seawater), range of $\mathrm{Cl} / \mathrm{Na}(<1)$ are determinate at the investigation area. And this ratio in the marine waters $=1.15$, in the fresh waters $=<1$. This ratio is 1.7 of Aegean sea water. The this ratio values are been of Cinarkaynak (S14) 1.2, of Kiyikislacik (S07) 35.4, of Sepetciler (S06) 0.7. In addition value is 12.3 in Savrankoy spring water (S05) that $800 \mathrm{~m}$ away from the Sepetciler spring water (S06), ranges of 0.2-6.8 of Ekinambari (S04) (Figure 10).

Especially $\mathrm{Cl} / \mathrm{Na}$ were higher than seawater in springs that S04, S05, S07, S08. The ratio $\mathrm{Cl} / \mathrm{Na}$ is been calculated considerably higher than seas, lakes and rivers value (Figure 10) where In the Basin wells drilled (Figure 11) from the Avsar, Ovakislacik, Selimiye, Becin, Korukoy and Milas center wells drilled.

The $\mathrm{Cl}$ values is a good indicator in subject of salinization. However, it was identified of the high chloride values increased in the spring waters away from the seashore in which ones as close to the shore (Figure 12). The high $\mathrm{Cl}$ value $(\mathrm{meq} / \mathrm{l})$ was determined at the spring waters (S05, S06, S12) that away to the seashore, when $\mathrm{Cl}$ change depending on the distance in the ones of the seashore are examined. However, the harmony is been between them when considering seawater mixture ratio (\%) (Figure 13, Table 2) with away to the seashore of the springs the high rate of seawater mixture is noteworthy is sea distance 11.44 and $11.73 \mathrm{~km}$ are between Savranköy (S05) with Sepetciler (S06) spring groups (Figure 14, Table 2). In wells, considering of depending on the distance to the seashore with a value of $\mathrm{Cl}(\mathrm{meq} / \mathrm{l})($ Figure 15, Table 2) and change of seawater mixture ratio (Table 2), the high value was found remarkable that Well 3 (16.5 km away from the seashore) and Well 29 (8.84 km away from the seashore) other than driling wells mixture of sea water of the wells compared.

\section{Discussion}

$\mathrm{Cl}$ content have been used by that for the determination of the contribution of sea water, precipitation, seawater from respective sampling point of $\mathrm{Cl}$ content. Origin of $\mathrm{Cl}$ content in freshwater that close to the shores in basin can be from seawater. In addition to rainwater added as result seaspray with $\mathrm{Cl}$; during the scattering of seawater resulting by evaporate of the water droplets $\mathrm{Cl}$ content, case of dry fall out of aerosols and accumulating on the surface

soil of these powders by melt with rainwater by interfere to groundwater; by dissolving $\mathrm{Cl}$ containing of minerals (etc. $\mathrm{NaCl}, \mathrm{KCl}$, volcanic origin as evaporite minerals) can have with gas $(\mathrm{Cl} 2)$ escape from magma (Hem, 1965; Kesler, 1994). As a result, of the increase of $\mathrm{Cl}$ in fossil water where occurs in aquifer but which remained underground for a long time and large circulation in length (about $100 \mathrm{~km}$ and more) (Appelo, and Postma, 1994). With of wide spread of mountainous areas in the study area, the aquifer can be explained by this model. Together with all other ions were been enriched with $\mathrm{Cl}$ ion concentration, because in the first few meters below the surface by leaking water due to evaporation.

When it is compared the $\mathrm{Cl}, \mathrm{Na}$ ve $\mathrm{Mg}(\%)$ rates of wells and springs with seawater all springs excluding S09 and S14 (Ovakislacik, Cinarkaynak) resent same features with seawater. As shown in Figure 16, Na ratio of S06 (Sepetciler) spring and $\mathrm{Cl}$ ratios of all springs have similar feature with seawater. The salinity of S07 (Kiyikislacik) spring can be explained with the close location to the sea and the effects of the tides, but the salinity of the other springs can not be explained with the same effect in respect of their locations. Thus, taking into consideration they were groundwater having the similar features with seawater, it can be concluded that these springs 
were effected by the mixture of seawater, even if their outlet point is above the sea level. In the Yasyer, Hamzabey and Avsar plains where the wells (Figure 1, section D) were drilled extensively, it was observed salinity varies according to the season. However, salinity was not detected in some wells in the region.
Salinization in some of the wells and no salinization in the others can not be explained with the distance from the sea. Because, in the Yasyer plain in the north of Hamzabey Plain, when proceeding to the eastern of the plain, salinity is increasing with the distance from the sea.

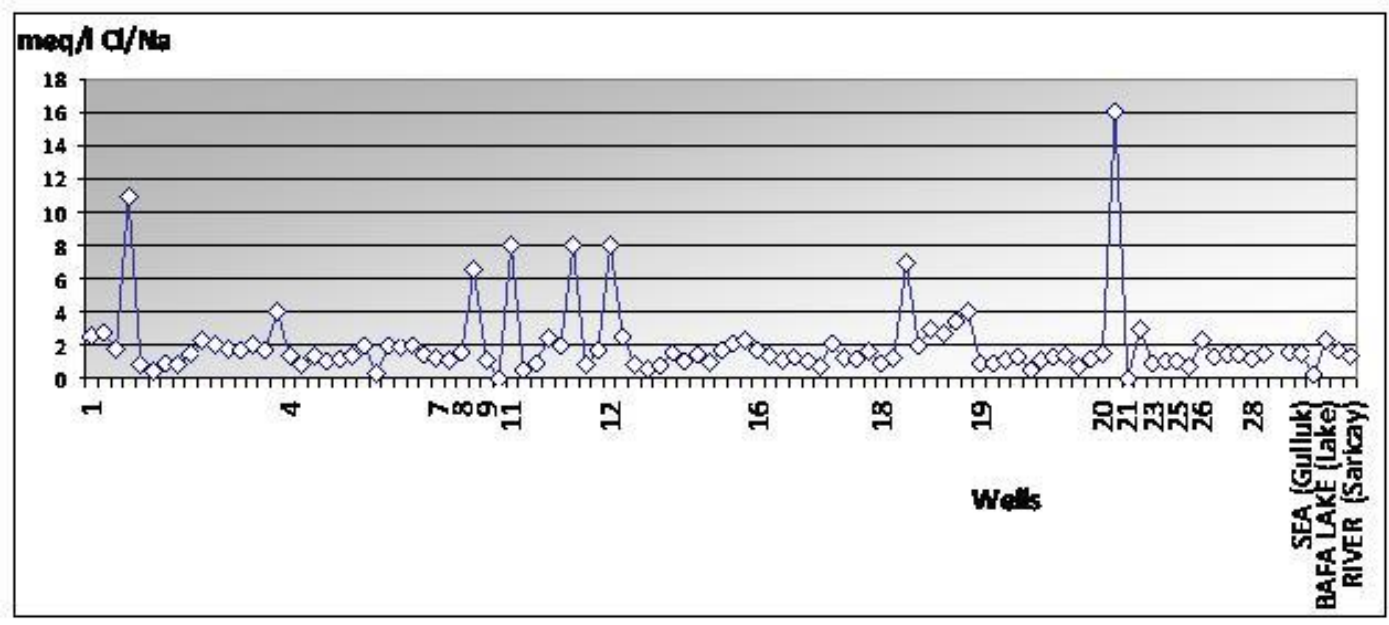

Fig. 11. Distribution of $\mathrm{Cl} / \mathrm{Na}$ ratios of wells, lake, stream and sea (Gulluk) at investigation area.

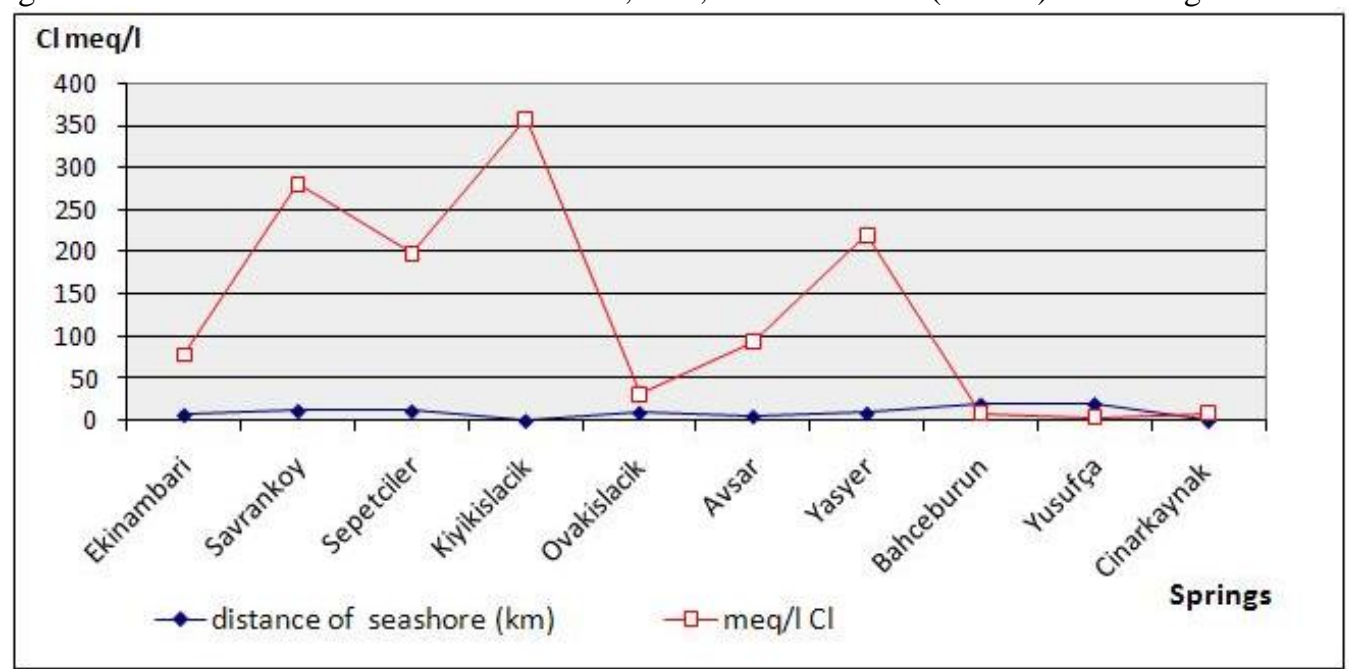

Fig.12. Distribution of $\mathrm{Cl}$ ratios and away from the sea shore of spring waters at investigation area.

Perissoratis and Conispoliatis (2003) in their study have made the definition of time slicings and determined that the sea level was $-120 \mathrm{~m}$ 21500 years ago (latest low position of the sea

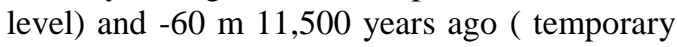
delay concerning sea level rise) and $-15 \mathrm{~m}$ 8.000 years ago. In ANDENES tide gauge station (in Norwegian coasts), it was determined that the long-term absolute sea level rises $2.44 \pm 0: 21 \mathrm{~mm} /$ year. This value is campatible with absolute sea level change of $3.2 \pm 1.5 \mathrm{~mm} /$ year and $2.6 \pm 1.0 \mathrm{~mm} /$ year determined by Sanli and Blewitt (2001) in the UK North Shields tide gauge stations by using respectively tide + GPS and sensitive geometric leveling measurements. Yildiz and Deniz (2006) in ANDENES tide gauge station determined that the the long-term absolute sea level of $2.44 \pm 0: 21 \mathrm{~mm} /$ year rises rapidly and compatible result with the value of global sea 
level changes of 1-3 mm/year given by Sanli and Blewitt (2001) was obtained. Sea -level rise, one of the effects of climate change, is observed due to sea water temperature causing the thermal expansion of sea water temperature and melting of glaciers, The research shows that the sea water level in 2100 compared to 1980 will be increased from 30 to $60 \mathrm{~cm}$ (IPCC, 2007).

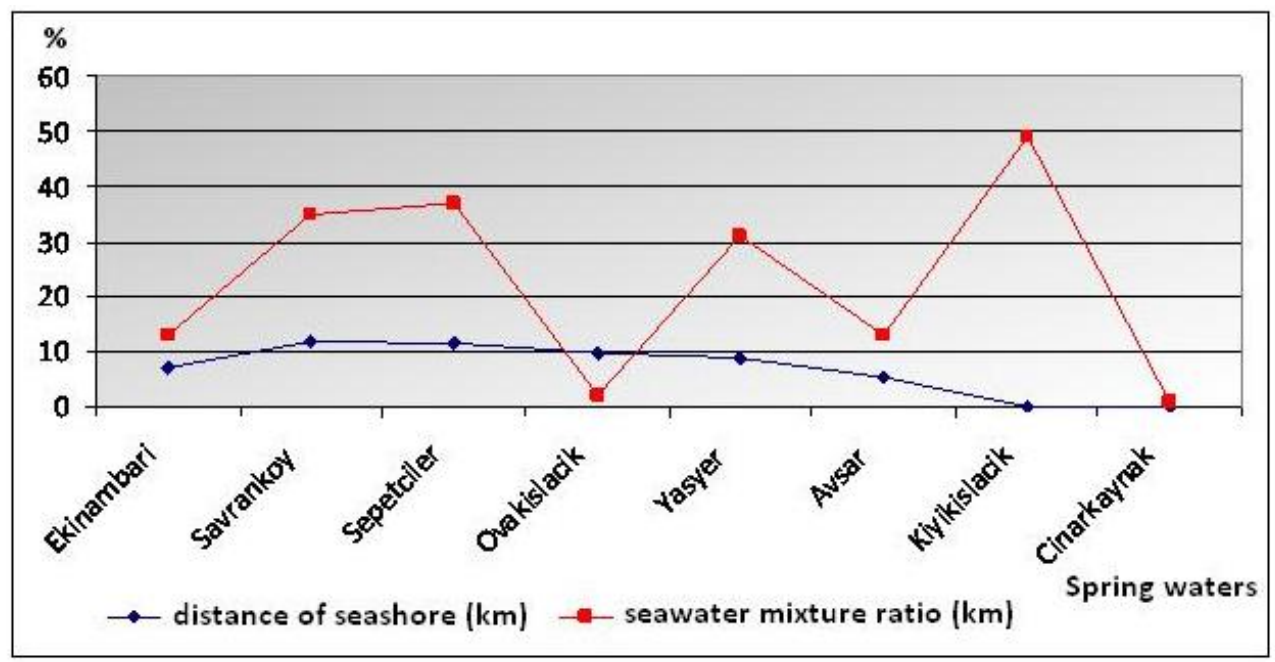

Fig. 13. Distribution of rate of seawater mixture of spring waters and length to the seashore at investigation area.

Even though,an evaluation is made that the salinization in wells and springs in the study area is not connected with the sea water in the Neogene sediments (Eroskay et al., 1992), it is an important finding that the saturation with seawater in the carstic levels of limestones deeper into the earth. In the data of Ovakislacik exploratory wells of DSI (wells 7, 8, 9, 10), the effect of seawater at lower levels supports this view. In the surface sections, Neogene sediments and limestones with non carstic less permeable and / or impervious surfaces illustrate the pressurized spring discharges. Groundwater salinity is directly related to nutrition quality and quantity, grundwater circulation in the saline environment and the position of the wells and springs in salty areas.

As the result of last glacial-eustatic origin uplifting of ocean levels, the Agean Sea was formed and the present geomorphological view of Agean sea based on the new stresses in the region, horizontal and vertical displacements (Erinç and Yücel, 1978). In a recent surveys (Erol, 1991) a steady rise in sea level of Anatolian costs is observed in the last 4000-
5000 years. Today, this sea level rise totally reached to 3-4 m. However, in response to this rise in sea level, the land continues to rise under the influence of tectonic movements. Thus, another important factor is crustal movements as well as the both movements balancing each other and the effects of climate change in the rise of sea level. The rise of sea level is calculated as a $=0.03097 \pm 0.00989 \mathrm{~cm} /$ month (Hekimoğlu et al., 1996). Here, the compatibility of the the trend value of 4.8 $\mathrm{mm} /$ year (Gürdal, 1998) with the average value of 0.5-3.0 mm / year (Pirazzoli, 1996) can be evaluated together.

The marine internal circulation in various directions, support the presence of existing springs in the sea. Considering the locations of the marine internal springs, a model is valid supporting sea water intrusion along the fault linearity. As a result; for the springs whose seawater mixture ratios calculated, although their outlet points are above sea level, it can be said that these springs have a model to support sea water interference along their discontinuity planes. 


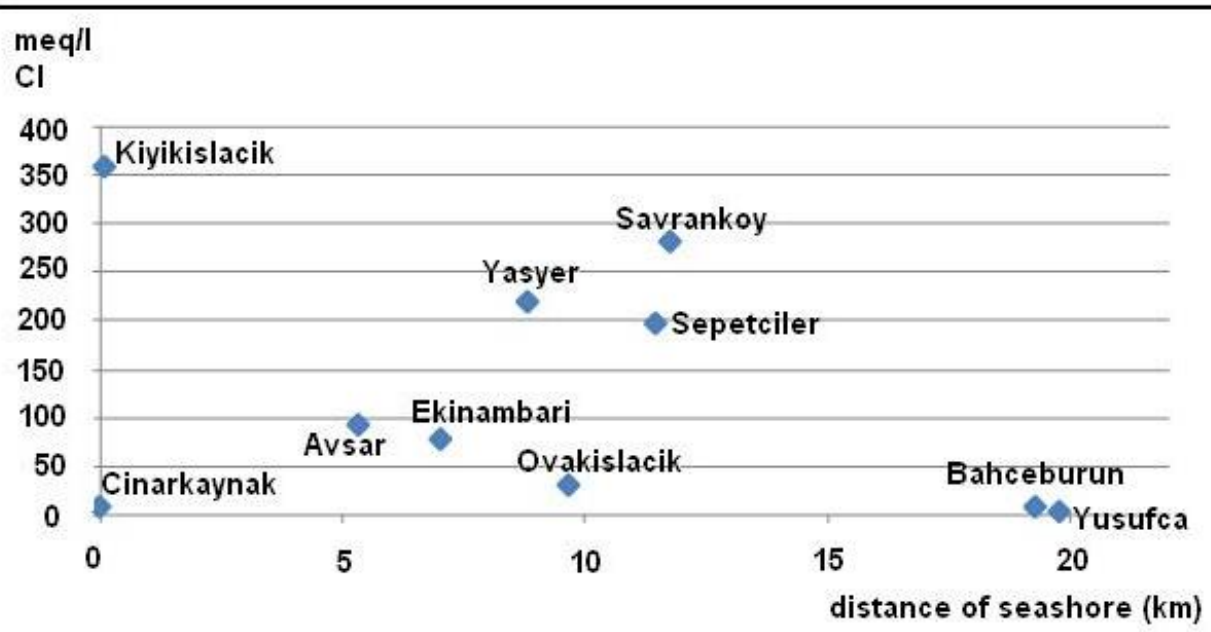

Fig.14. Distribution of rate of seawater mixture of spring waters and length to the seashore at investigation area.

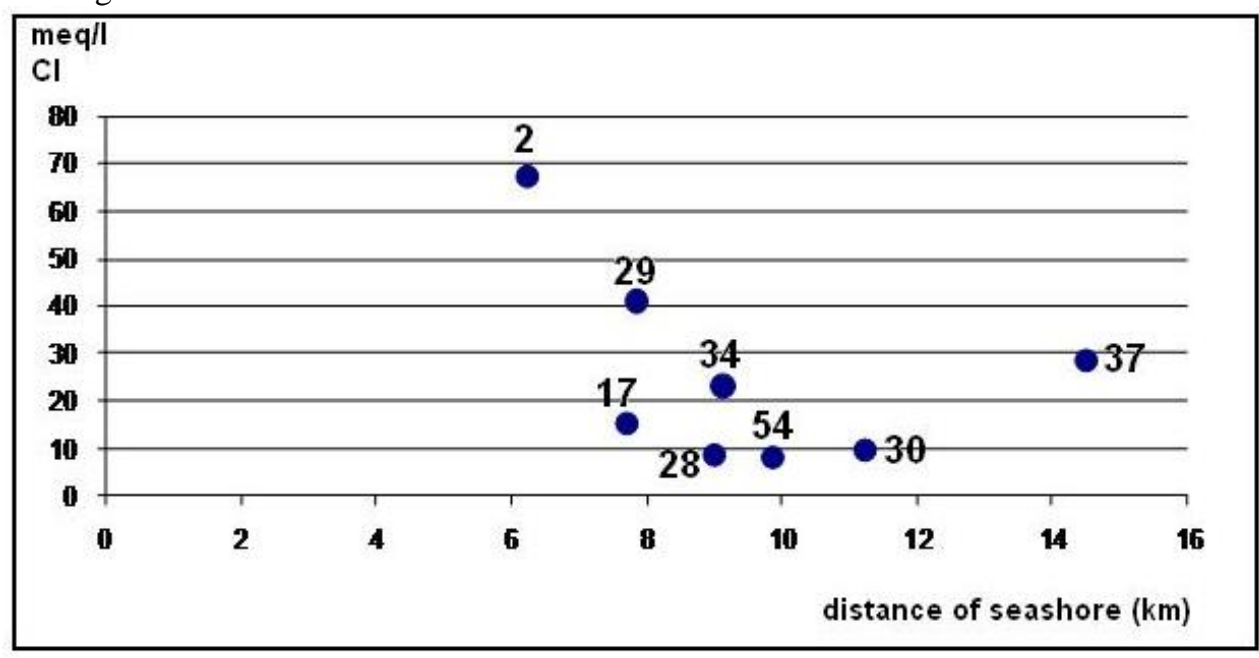

Fig.15. Distribution of rate of seawater mixture of representative wells and length to the seashore at investigation area.

\section{Conclusions}

The low level of $\mathrm{Ca}(\mathrm{Mg})$ and $\mathrm{HCO}_{3}$ ion concentrations and high $\mathrm{pH}$ accelerate calcite precipitation. Therefore, calcite is rapidly precipitated in spring waters of $\mathrm{S} 01, \mathrm{~S} 09, \mathrm{~S} 03$, $\mathrm{S} 10$. Calcite is slowly precipitated in the spring waters of S05, S07, S11, S12.

Salinity is high considering the seasonal changes in springs and wells, salinization of the geological structure of the model was determined to be in control. However, in the formation of karstic water springs in the study area; have supported the idea from aluviyal discharges by faults of that control of the Yatagan formation of with impervious and pervious level.

Consequently, four water groups can be distinguished: (a) Samples with $\mathrm{Cl}-<20$ meq/l and $\delta 180<-4.8 \%$ are interpreted as fresh groundwater, recharged from meteoric water. (S01, S02, S03, S09, S10, S13, S14). (b) Samples enriched in ${ }^{18} \mathrm{O}$ with a small increase in chloride content resulting from evaporation. Field observations confirmed that spring waters (S04, S05, S06, S07, S08, S10, S11, S12) and wells are used, whereas are exploited normally; thus, the return flow from irrigation seems to be 
the main recharge process and the cause of their relatively increased salinity. (c) Samples at the top in with similar $\delta 180$ values and high chloride/sodium content of spring water can be formed through salt intrusion; this may be the infiltrated located in the vicinity of discharge, and seawater intrusion for the coastal wells.

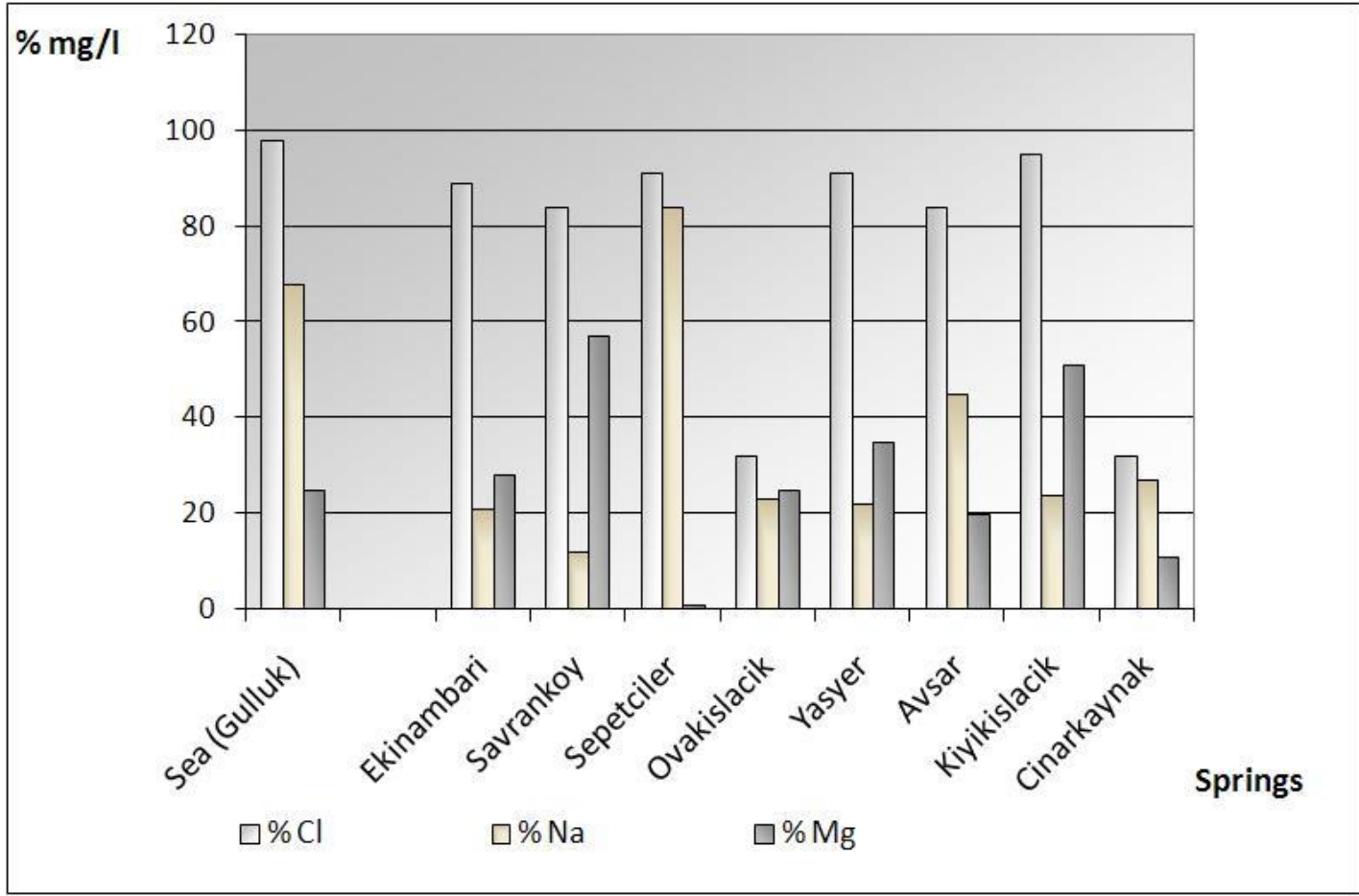

Fig. 16. $\mathrm{Cl}, \mathrm{Na}$ ve $\mathrm{Mg}(\%)$ rates of spring waters.

The relationship ${ }^{18} \mathrm{O}-{ }^{2} \mathrm{H}$, terrestrial line in between seawater and waters in the study area has been identified. Here it is not possible to speak from mixture of seawater. However, other than these two lines in Region A of waters situated, mixture of seawater been determined.

Considering the relationship EC- ${ }^{18} \mathrm{O}$, situation of springs and drilling wells can be explained by the effect of evaporation. The review is global water [0 (zero) sampling points at the intersection] at the region of ground water that $\mathrm{EC}=0$ (zero), have been participated meteoric water from high elevation from the feeding areas to the hydrogeological system indicates that they have washed with salty formation.

\section{Acknowledgements}

This study was supported project is a part of TUBITAK 197Y115 (YDABÇAG-588 / A).
The author would like to thank to the Turkish State Meteorology Services for supply the meteorological data. And also sincerely thank to General Directorate of State Hydraulic Works-Research Department/ Isotope Laboratory for isotope analysis, and to İstanbul University/ Faculty of Engineering Labs for the anion and cation analysis.

\section{References}

APHA, (1992). Standard Methods For The Determination Of Water And Wastewater. American Public Health Association Publication, 18th edition, Washington DC.

Appelo, C.A.J., Postma, D. (1994). Geochemistry, Groundwater and Pollution. A.A.Balkema/Rotterdam/Brookfield, 2nd Ed., Netherlands.

Barut, I.F. (2001). Milas-Ekinambarı ve Savran Tuzlu Kaynaklarının Hidrokimyasal 
Araştırması. $\mathrm{PhD}$ Thesis. Istanbul University, Istanbul. (In Turkish with English abstract).

Barut, I.F., Gurpinar, O. (2005). An approach to the hydrogeological circulation model of the salty karstic springs in the Milas (Mugla) basin. Univ. Istanbul J. Earth Sci., 18 (1), 1-22, (In Turkish with English abstract).

Chadha D.K. (1999). A proposed new diagram for geochemical classification of natural waters and interpretation of chemical data. Hydrogeology Journal, 7, 431-439.

Craig, H. (1961). Students for Reporting Concentrations Of Deuterium And Oxygen In Natural Waters. Science, 133, 1833-1834.

Erinç, S., Yücel, T. (1978). Ege Denizi, Türkiye ile Komşu Ülke Adaları. Türk Kültürünü Araştırma Enstitüsü, 50, VII, A-3, Ankara, (In Turkish).

Erol, O. (1991). Impacts of sea-level rise on Turkey. International Sea-Level Rise Studies Project, Institute of Marine and Coastal Sciences Rutgers-The State University of New Jersey, New Brunswick, USA.

Eroskay, S.O., Gurpinar, O., Gozubol, A.M., Senyuva, T. (1992). Geological and Hydrogeological Investigation on MuğlaGökova and Milas-Savran ve Ekinambarı Karst Springs. Final Report, İstanbul University. (In Turkish with English abstract).

Hekimoglu, S., Ayhan, M.E., Demir, C., Sanli, D., Kahveci, M. (1996). Project for Turkish National Vertical Datum Determination. Yıldız Technical University, Research Fund. Civil Engineering Faculty, Department of Geodesy and Photogrammetry. Issue No. 16. İstanbul, (In Turkish).

Gimenez, E., (1994). Caracterizacion hidrogeoqu_1mica de los procesos de salinizacion en el acuifero detritico costero de la Plana de Castellon (Espana). PhD Thesis. Univ. de Granada.

Gurdal, M.A. (1998). Deniz Seviyesi Ölçümleri ve Harita Genel Komutanlığınca İşletilen Mareograf İstasyonları. Harita Genel Komutanlığ $\breve{l}$ Harita Dergisi, 119, 1-14. (In Turkish with English abstract).

Hem, J.D. (1965). Study and interpretation of the chemical characteristics of natural water. Geological Survey Water-Supply
Paper 1473, US Goverment Printing Office, 2nd edition, Washington DC.

IPCC, (2007). Contribution of Working Group I to the Fourth Assessment Report of the Intergovernmental Panel on Climate Change. In: Solomon, S., Qin, D., Manning, M., Chen, Z., Marquis, M., Averyt, K.B., Tignor, M. and Miller, H.L. (eds.), Cambridge University Press, Cambridge, United Kingdom and New York, NY, USA.

Jones, B.F., Vengosh, A., Rosenthal, E., Yechieli, Y. (1999). Geochemical investigations. In: Bear, J., Cheng, A.H.D., Sorek, S., Quazar, D., Herrera, I. (Eds.), Seawater Intrusion in Coastal Aquifers. Kluwer Academic Publishers, Dordrecht, Holand, 51-71.

Kayan, I., Klemas, V. (1978). Application Of Landsat Imagery To Studies Of Structural Geology And Geomorphology Of The Menteşe Region of SW Turkey. Remote Sensing of Environment, An Interdisciplinary Journal 7, 51-60.

Kesler, E.S. (1994). Mineral Resources, Economics and the Environment. Mc Millan College Publishing Com.Inc., New York.

Kurttas, T. (1997). Environmental isotope study of Gökova (Muğla) karstic springs. Hacettepe University, PhD Thesis. (In Turkish with English abstract).

Onhon, E., Ozdamar, A.R., Kaplan, A. (1998). Karst Hydrogeological Investigation of Selimiye-Milas-Ekinambarı Basin. DSI Report, Aydin.

Perissoratis, C., Conispoliatis, N. (2003). The impacts of sea-level changes during latest

Pleistocene and Holocene times on the morphology of the Ionian and Aegean seas (SE Alpine Europe), Marine Geology, 196, 145-156.

Piper, A.M. (1953). A graphic procedure in the geochemical interpretation of water analyses. US Geological Survey, Groundwater Note 12, Washington DC.

Pirazzoli, P.A. (1996). Sea-Level Changes: The Last 20000 Years. Wiley-Blackwell, Chichester, UK.

Pulido-Leboeuf, P. (2002). Contribucion al conocimiento de acuiferos costeros complejos. Caso de Castell de Ferro. Serv. Publ. Univ. Almeria.

Sanchez-Martos, F., Pulido-Bosch, A., Calaforra, J.M. (1999). Hydrogeochemical 
processes in an arid region of Europe
(Almeria,
SE Spain).
Applied

Geochemistry. 14, 735-745.

Sanli, D.U., Blewitt, G. (2001). Geocentric sea level trend using GPS and >100-year tide gauge record on a postglacial rebound nodal line. Journal of Geophysical Research, 106, (B1), 713 -719.

Y1ldı, H., Deniz, R. (2006). Mareograf ve Sabit GPS ile Uzun Dönemli Mutlak Deniz Seviyesi Değişimleri, İtü Dergisi/dMühendislik, 5(3), 1,115-125. (In Turkish with English abstract). 